\title{
Sources and transformations of anthropogenic nitrogen along an urban river-estuarine continuum
}

\author{
Michael J. Pennino ${ }^{1, \text { a }}$, Sujay S. Kaushal ${ }^{1}$, Sudhir N. Murthy ${ }^{2}$, Joel D. Blomquist ${ }^{3}$, Jeff C. Cornwell ${ }^{4}$, and \\ Lora A. Harris ${ }^{5}$ \\ ${ }^{1}$ Department of Geology and Earth Systems Science Interdisciplinary Center, University of Maryland, \\ College Park, MD, USA \\ ${ }^{2}$ DC Water, Office of the General Manager, Washington, D.C., USA \\ ${ }^{3}$ US Geological Survey, Maryland, Delaware, and District of Columbia Water Science Center, Baltimore, MD, USA \\ ${ }^{4}$ Center for Environmental Science, University of Maryland Horn Point Laboratory, Cambridge, MD, USA \\ ${ }^{5}$ Center for Environmental Science, University of Maryland Chesapeake Biological Laboratory, Solomons, MD, USA \\ a now at: US EPA, Office of Research and Development, National Health and Environmental Effects Research Laboratory, \\ Corvallis, OR, USA
}

Correspondence to: Michael J. Pennino (michael.pennino@gmail.com)

Received: 19 June 2016 - Published in Biogeosciences Discuss.: 11 July 2016

Revised: 20 October 2016 - Accepted: 25 October 2016 - Published: 18 November 2016

\begin{abstract}
Urbanization has altered the fate and transport of anthropogenic nitrogen $(\mathrm{N})$ in rivers and estuaries globally. This study evaluates the capacity of an urbanizing river-estuarine continuum to transform $\mathrm{N}$ inputs from the world's largest advanced (e.g., phosphorus and biological $\mathrm{N}$ removal) wastewater treatment facility. Effluent samples and surface water were collected monthly along the Potomac River estuary from Washington D.C. to the Chesapeake Bay over a distance of $150 \mathrm{~km}$. In conjunction with box model mass balances, nitrate stable isotopes and mixing models were used to trace the fate of urban wastewater nitrate. Nitrate concentrations and $\delta^{15} \mathrm{~N}$ $\mathrm{NO}_{3}^{-}$values were higher down-estuary from the Blue Plains wastewater outfall in Washington D.C. $\left(2.25 \pm 0.62 \mathrm{mg} \mathrm{L}^{-1}\right.$ and $25.7 \pm 2.9 \%$, respectively) compared to upper-estuary concentrations $\left(1.0 \pm 0.2 \mathrm{mg} \mathrm{L}^{-1}\right.$ and $9.3 \pm 1.4 \%$, respectively). Nitrate concentration then decreased rapidly within $30 \mathrm{~km}$ down-estuary (to $0.8 \pm 0.2 \mathrm{mg} \mathrm{L}^{-1}$ ), corresponding to an increase in organic nitrogen and dissolved organic carbon, suggesting biotic uptake and organic transformation. TN loads declined down-estuary (from an annual average of $48000 \pm 5000 \mathrm{~kg} \mathrm{day}^{-1}$ at the sewage treatment plant outfall to $23000 \pm 13000 \mathrm{~kg} \mathrm{day}^{-1}$ at the estuary mouth), with the greatest percentage decrease during summer and fall. Annually, there was a $70 \pm 31 \%$ loss in wastewater $\mathrm{NO}_{3}^{-}$along the
\end{abstract}

estuary, and $28 \pm 6 \%$ of urban wastewater TN inputs were exported to the Chesapeake Bay, with the greatest contribution of wastewater TN loads during the spring. Our results suggest that biological transformations along the urban riverestuary continuum can significantly transform wastewater $\mathrm{N}$ inputs from major cities globally, and more work is necessary to evaluate the potential of organic nitrogen and carbon to contribute to eutrophication and hypoxia.

\section{Introduction}

Urbanization and agriculture have greatly increased the exports of nitrogen from coastal rivers and estuaries globally, contributing to eutrophication, hypoxia, harmful algal blooms, and fish kills (e.g., Aitkenhead-Peterson et al., 2009; Kaushal et al., 2014b; Nixon et al., 1996; Petrone, 2010; Vitousek et al., 1997). Despite billions of dollars spent on regulatory and technological improvements for wastewater treatment plants (WWTPs) and agricultural and urban stormwater runoff (e.g., US-EPA, 1972, 2009, 2011), many coastal waters are still impaired. Also, there are major questions regarding how far urban sources of $\mathrm{N}$ (wastewater and stormwater runoff) are transmitted along tidal river-estuarine networks to $\mathrm{N}$-sensitive coastal receiving waters. This study evaluates 
the capacity of a major river-estuarine system to transform and attenuate $\mathrm{N}$ inputs from the world's largest advanced (e.g., phosphorus and biological nitrogen removal) wastewater treatment plant (Blue Plains) before being transported down-estuary to the Chesapeake Bay. We used a combination of stable isotope and box model mass balance approaches to track the fate and transport of anthropogenic nitrogen across space and time.

In addition to urban and agricultural inputs, altered riverestuarine hydrology can contribute to higher exports of $\mathrm{N}$. Jordan et al. (2003) found that annual water discharge increased as the proportion of developed land in a coastal watershed increased. Higher flows, typically during winter and spring months, have also been associated with higher $\mathrm{N}$ loads in coastal river estuaries (Boynton et al., 2008). Furthermore, regional climate variability amplifies pulses of nutrients and other contaminants in rivers (Easterling et al., 2000; IPCC, 2007; Kaushal et al., 2010b; Saunders and Lea, 2008) and alters the biotic transformation of $\mathrm{N}$ due to changes in hydrologic residence times (Hopkinson and Vallino, 1995; Kaushal et al., 2014b; Wiegert and Penaslado, 1995). For example, high-flow periods related to storms can induce stratification and impact salinity regimes (Boesch et al., 2001), which affects nutrient biogeochemistry like ammonium and phosphate concentrations (Jordan et al., 2008). An improved understanding of the longitudinal assimilatory capacity for nitrogen by large river-estuarine systems across different flow regimes is needed for guiding effective coastal river and estuarine management strategies.

One critical and innovative approach to effectively manage coastal nutrient pollution is to (1) track the relative contributions of $\mathrm{N}$ export from different sources within the watershed and (2) understand the potential for longitudinal transformation within coastal rivers and estuaries. Recent studies using stable isotopes (Kaushal et al., 2011; Kendall et al., 2007; Oczkowski et al., 2008; Wankel et al., 2006) have shown that these methods can be helpful in elucidating sources and transformations of nitrogen. However, these studies are typically conducted at relatively smaller spatial scales and without coupling to mass balance approaches over both time and space.

Here, we combine isotope and mass balance approaches to track sources and transformations of urban wastewater inputs to the Chesapeake Bay over space and time across an urban river-estuary continuum spanning over $150 \mathrm{~km}$. The spacetime continuum approach has previously been used in studying fate and transport of carbon and nitrogen in urban watersheds (Kaushal and Belt, 2012; Kaushal et al., 2014c), and here we explore extending it to river and estuarine ecosystems. Our overarching questions were as follows. (1) How does the importance of point vs. non-point sources of $\mathrm{N}$ shift along a tidal and stratified urban river-estuary continuum across space and time? (2) What is the capacity of an urban river-estuary continuum to transform or assimilate anthropogenic $\mathrm{N}$ inputs? (3) How are transport and transforma-

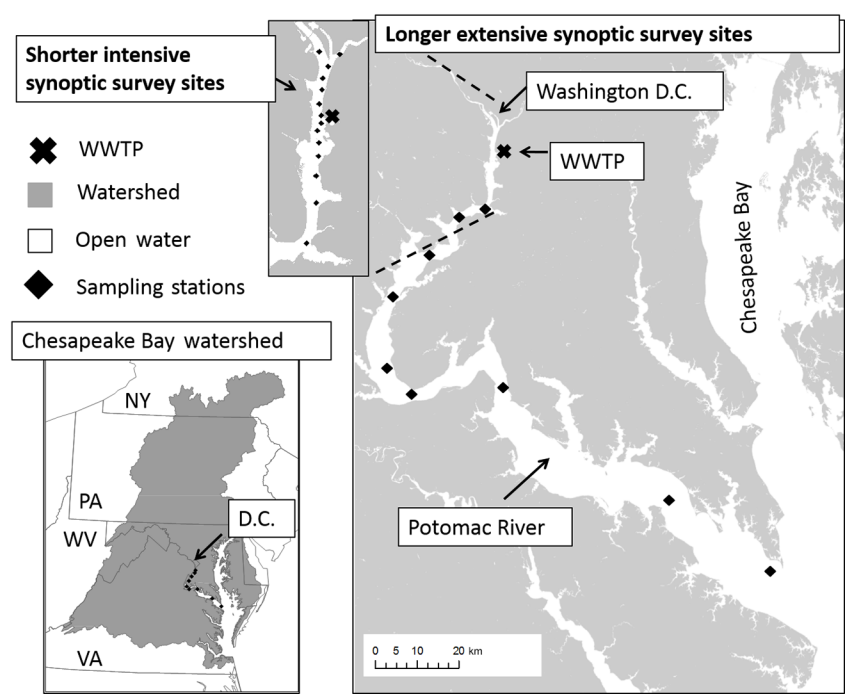

Figure 1. Map showing the Potomac River sampling stations (black diamond) and the location of the Blue Plains Wastewater Treatment plant (WWTP, black X) just south of Washington D.C., within the Chesapeake Bay watershed. The larger figure shows the location of monthly extensive synoptic surveys sites and the smaller panel on upper left shows the locations of the shorter intensive synoptic surveys. The larger panel also shows the location for the historical Maryland DNR surface water sampling sites.

tions of $\mathrm{N}$ affected by differences in season or hydrology? An improved understanding of how sources and transformations of $\mathrm{N}$ change along the urban river-estuarine continuum over space and time can inform management decisions regarding $\mathrm{N}$ source reductions along urbanizing coastal watersheds (e.g., Boesch et al., 2001; Kaushal and Belt, 2012; Paerl et al., 2006).

\section{Methods}

\subsection{Site description}

This study is focused on the tidal Potomac River estuary, which includes the section of the river from Washington D.C. to its confluence with the Chesapeake Bay (Fig. 1). The Potomac River estuary begins as tidal freshwater, becoming oligohaline $\sim 30-50 \mathrm{~km}$ below Washington D.C. and mesohaline at its mouth approximately $160 \mathrm{~km}$ below Washington D.C. (Jaworski et al., 1992). The Potomac River estuary can be seasonally stratified (Hamdan and Jonas, 2006), especially in the southern portion of the system where intruding, saline bottom water from the main stem of the Chesapeake Bay leads to density-driven estuarine circulation patterns (Elliott, 1976, 1978; Pritchard, 1956). Mixing is most evident at the estuarine turbidity maximum (Hamdan and Jonas, 2006), $\sim 60-80 \mathrm{~km}$ down-estuary of Washington D.C., and the water column is generally well mixed above the estuarine turbidity maximum zone in the tidal fresh and oligohaline re- 
gions of the estuary (Crump and Baross, 1996; Sanford et al., 2001).

The watershed draining to the Potomac River estuary is classified as $58 \%$ forested, $23 \%$ agricultural, and $17 \%$ urban, based on Maryland Department of Planning data for 2002 (Karrh et al., 2007a). Based on the Chesapeake Bay Program (CBP) model it was estimated that, during 2005, total inputs of nitrogen were $33 \%$ from agriculture, $20 \%$ from urban (e.g., stormwater runoff and leaky sewers), $19 \%$ from point sources (wastewater treatment plants and industrial releases), $11 \%$ from forest, $10 \%$ from septic, $6 \%$ from mixed open land, and $1 \%$ from atmospheric deposition to water (Karrh et al., 2007b). The CBP model is developed using long-term monitoring data and the non-point loads are estimated from a variety of sources including land cover and agriculture records (Karrh et al., 2007b).

The Potomac River estuary also receives $\mathrm{N}$ inputs from the Blue Plains wastewater treatment plant, located in Washington, D.C. In 2009 Blue Plains discharged $2.3 \mathrm{mg} \mathrm{L}^{-1}$ of $\mathrm{NO}_{3}^{-}$and $3.7 \mathrm{mg} \mathrm{L}^{-1}$ of $\mathrm{TN}$, on average, and exported loads of approximately $2300 \mathrm{~kg} \mathrm{day}^{-1}$ of $\mathrm{NO}_{3}^{-}$and $3900 \mathrm{~kg}$ of TN. Overall, Blue Plains treats and discharges approximately $1.06 \times 10^{9} \mathrm{Lday}^{-1}$, almost $5 \%$ of Potomac River's annual discharge. In the past several decades, Blue Plains has undergone several technological improvements with phosphorus removal in the 1980 s and enhanced $\mathrm{N}$ removal beginning in the year 2000. Since the implementation of advanced wastewater treatment technologies at Blue Plains, there has been a significant decrease $(p<0.01)$ in the concentration of nitrate in effluent discharge, from an average of $7.2 \pm 0.3 \mathrm{mg} \mathrm{L}^{-1}$ before the year 2000 (years 1998 and 1999) to an average of $4.1 \pm 0.4 \mathrm{mg} \mathrm{L}^{-1}$ directly after 2000 (years 2001 through 2008).

\subsection{Analysis of long-term spatial and temporal water chemistry data}

Surface and bottom water $\mathrm{N}$ and carbon data collected by the Maryland Department of Natural Resources (DNR) and accessed through the Chesapeake Bay Program's Data Hub website (Chesapeake Bay Program, 2013) was used to look at historical (1984 to 2012) monthly nutrient concentrations from stations located longitudinally along the Potomac River estuary (Fig. 1). In particular, these data were used for analyzing the spatial and temporal trends for dissolved and particulate forms of $\mathrm{N}$ and dissolved organic carbon (DOC) in the Potomac River estuary prior to and during this study.

\subsection{Water chemistry sampling}

Water chemistry samples along the Potomac River estuary were collected monthly for 1 year from April 2010 to May 2011; from 12 to $160 \mathrm{~km}$ below the Blue Plains wastewater treatment plant (See Fig. 1). Water was collected from the surface (top $0.5 \mathrm{~m}$ ) and bottom water depths. Surface wa- ter samplings from 6 above to $12 \mathrm{~km}$ below the Blue Plains wastewater treatment plant effluent outfall were collected seasonally during this time (Fig. 1). Water temperature and salinity were also measured during each water chemistry sampling.

\subsection{Nitrate $\delta^{15} \mathrm{~N}$ and $\delta^{18} \mathrm{O}$ isotope analyses}

Surface samples for $\delta^{15} \mathrm{~N}-\mathrm{NO}_{3}^{-}$and $\delta^{18} \mathrm{O}-\mathrm{NO}_{3}^{-}$isotopes of dissolved nitrate were filtered $(0.45 \mu \mathrm{m})$, frozen, and shipped to the UC Davis Stable Isotope Facility (SIF) for analysis. The isotope composition of nitrate was measured following the denitrifier method (Casciotti et al., 2002; Sigman et al., 2001). In brief, denitrifying bacteria are used to convert nitrate in samples to $\mathrm{N}_{2} \mathrm{O}$ gas, which is collected and sent through a mass spectrometer for determination of the stable isotopic ratios for $\mathrm{N}$ and $\mathrm{O}$ of nitrate $\left({ }^{15} \mathrm{~N} /{ }^{14} \mathrm{~N}\right.$ and ${ }^{18} \mathrm{O} /{ }^{16} \mathrm{O}$ ). Values for $\delta^{15} \mathrm{~N}_{-} \mathrm{NO}_{3}^{-}$and $\delta^{18} \mathrm{O}-\mathrm{NO}_{3}^{-}$are reported as per mill $(\% \circ)$ relative to atmospheric $\mathrm{N}_{2}\left(\delta^{15} \mathrm{~N}\right)$ or Vienna Standard Mean Ocean Water (VSMOW; $\delta^{18} \mathrm{O}$ ), according to $\delta^{15} \mathrm{~N}$ or $\delta^{18} \mathrm{O}(\%)=[(R)$ sample $/(R)$ standard $1] \times 1000$, where $R$ denotes the ratio of the heavy to light isotope $\left({ }^{15} \mathrm{~N} /{ }^{14} \mathrm{~N}\right.$ or $\left.{ }^{18} \mathrm{O} /{ }^{16} \mathrm{O}\right)$. For data correction and calibration, UC Davis SIF uses calibration nitrate standards (USGS 32, USGS 34, and USGS 35) supplied by NIST (National Institute of Standards and Technology, Gaithersburg, MD). The long-term standard deviation for nitrate isotope samples at UC Davis SIF is $0.4 \%$ for $\delta^{15} \mathrm{~N}^{-\mathrm{NO}_{3}^{-}}$and

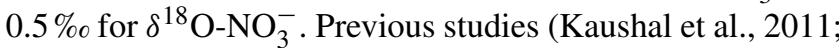
Kendall et al., 2007) indicate that the relative amounts of $\delta^{15} \mathrm{~N}-\mathrm{NO}_{3}^{-}$and $\delta^{18} \mathrm{O}-\mathrm{NO}_{3}^{-}$can be used to determine specific sources of nitrate (i.e., fertilizer, nitrification, atmospheric, or sewage derived nitrate).

It should be noted that while the denitrifier method converts sample $\mathrm{NO}_{3}^{-}$and $\mathrm{NO}_{2}^{-}$to $\mathrm{N}_{2} \mathrm{O}$ gas, in marine systems, $\mathrm{NO}_{2}^{-}$has been shown to complicate interpretations of the $\mathrm{N}$ and $\mathrm{O}$ isotopes of $\mathrm{NO}_{3}^{-}$if it remains unaccounted for (e.g., Fawcett et al., 2015; Marconi et al., 2015; Rafter et al., 2013; Smart et al., 2015). This is partially because during the reduction of $\mathrm{NO}_{3}^{-}$and $\mathrm{NO}_{2}^{-}$to $\mathrm{N}_{2} \mathrm{O}$ by the denitrifiers, the $\mathrm{O}$ isotope effects are different (and thus need to be corrected for). In addition, the $\delta^{15} \mathrm{~N}$ of $\mathrm{NO}_{2}^{-}$can be extremely different from that of $\mathrm{NO}_{3}^{-}$, potentially further complicating interpretation of the data. We found that in the Potomac Estuary stations TF2.1 through LE2.3 (stations from the top of the estuary to the bottom of the estuary) the mean nitrite concentration from 2010 to 2012 is $0.013 \mathrm{mg} \mathrm{L}^{-1}$, with a minimum of $0.0055 \mathrm{mg} \mathrm{L}^{-1}$ and maximum of $0.0183 \mathrm{mg} \mathrm{L}^{-1}$. The mean nitrite is about $2.4 \%$ of the mean nitrate +nitrite concentration. Based on the literature (Fawcett et al., 2015), this level of nitrite is still high enough to have some impacts on the nitrate isotope values, with differences up to $5 \%$ o for both $\mathrm{N}$ and $\mathrm{O}$ isotopes of nitrate when using the denitrified method 
with and without nitrite mixed with nitrate in the samples (Casciotti and McIlvin, 2007).

\subsection{Nitrate isotope mixing model}

To distinguish between the different potential nitrate sources we used a Bayesian isotope mixing model (Parnell et al., 2010, 2013; Xue et al., 2012; Yang and Toor, 2016). For the Bayesian isotope mixing model, the Stable Isotope Analysis in R (SIAR) package was used to determine the fraction of nitrate in each sample from four different sources: wastewater, atmospheric deposition, nitrification, and nitrate fertilizer (Parnell et al., 2010, 2013; Xue et al., 2012; Yang and Toor, 2016). The SIAR mixing model is able to incorporate uncertainty in nitrate source estimates based on the uncertainty in the nitrate source endmembers (Parnell et al., 2010, 2013; Xue et al., 2012; Yang and Toor, 2016).

Nitrate source endmember values for $\delta^{15} \mathrm{~N}-\mathrm{NO}_{3}^{-}$and $\delta^{18} \mathrm{O}-\mathrm{NO}_{3}^{-}$were obtained from the literature, except wastewater nitrate, which was obtained from this study. The endmember values for $\delta^{15} \mathrm{~N}_{-} \mathrm{NO}_{3}^{-}$and $\delta^{18} \mathrm{O}-\mathrm{NO}_{3}^{-}$were $-10.3 \pm 1.7$ and $10.1 \pm 1.5$, respectively, for nitrate from nitrification (Mayer et al., 2001); $0 \pm 3$ and $22 \pm 3$, respectively, for $\mathrm{NO}_{3}^{-}$fertilizer (Mayer et al., 2002); and $3 \pm 3$ and $69 \pm 5$, respectively, for atmospheric nitrate (Burns and Kendall, 2002; Divers et al., 2014). The wastewater $\delta^{15} \mathrm{~N}$ $\mathrm{NO}_{3}^{-}$and $\delta^{18} \mathrm{O}-\mathrm{NO}_{3}^{-}$endmember values $(31.5 \pm 7.8$ and $11 \pm 4.5$, respectively) were based on averaging the effluent nitrate isotope values measured monthly from Blue Plains during the study period. The nitrification source represents $\mathrm{NO}_{3}^{-}$from nitrification in the water as well as nitrification of ammonia fertilizer in the watershed. The fertilizer source represents synthetically produced $\mathrm{NO}_{3}^{-}$fertilizer, not the more common ammonia fertilizer. Animal manure was not used as one of the endmembers because this source is more significant in the upper Potomac River, above Washington, D.C. compared to the lower Potomac River watershed. For example, there are 171 concentrated animal feeding operation (CAFOs) in upper Potomac compared to 25 CAFOs in the lower Potomac below Washington, D.C. (US EPA, 2016).

Due to the variability in nitrate source endmembers, the mixing model was used primarily for illustrative purposes and should be viewed with caution. For example, there can be high variability in the nitrification source endmembers because nitrate from nitrification can come from ammonia fertilizer, manure fertilizer, particulate organic matter within the water column, etc. The nitrate from nitrification will therefor carry a range of nitrate isotope values reflecting its original source (Kendall et al., 2007). Also, because denitrification is known to cause the increase in $\delta^{15} \mathrm{~N}^{-\mathrm{NO}_{3}^{-}}$and $\delta^{18} \mathrm{O}$ $\mathrm{NO}_{3}^{-}$values through isotopic fractionation in approximately a $2: 1$ relationship (Divers et al., 2014; Kendall et al., 2007), this isotopic enrichment can complicate the identification of wastewater nitrate. For example, water samples with increased wastewater nitrate, based on the mixing model, may also indicate denitrification has played a role in the isotopic levels of the sample nitrate. As a result, there is a potential to overestimate the contribution of nitrate from wastewater if denitrification is occurring in the estuary.

\subsection{Salinity vs. nitrate concentrations and isotope mixing plots}

An additional method using plots of salinity vs. $\mathrm{NO}_{3}^{-}$concentration or $\mathrm{NO}_{3}^{-}$isotopes was used to assess whether there is conservative mixing (dilution), or mixing with additional $\mathrm{NO}_{3}^{-}$sources down-estuary, or losses of $\mathrm{NO}_{3}^{-}$through biotic uptake or denitrification (Middelburg and Nieuwenhuize, 2001; Wankel et al., 2006). Mixing line equations for $\mathrm{NO}_{3}^{-}$concentrations were based on equations 1-3 from Middelburg and Nieuwenhuize (2001) and isotopes mixing lines were based on equation 4 from Middelburg and Nieuwenhuize (2001). The mixing line equations and endmember values used for salinity and nitrate isotopes are provided in the Supplement (Table S2). Based on those equations, the salinity vs. $\mathrm{NO}_{3}^{-}$concentration mixing lines are linear, while the mixing lines for $\mathrm{NO}_{3}^{-}$isotopes are nonlinear (Middelburg and Nieuwenhuize, 2001). Wankel et al. (2006) suggest that when nutrient concentrations fall above the mixing line, this indicates an additional source to raise the concentrations, while concentrations that fall below the mixing line indicate that there is a nutrient sink (e.g., denitrification, assimilation). For nitrate isotopes, when the $\delta^{15} \mathrm{~N}^{-\mathrm{NO}_{3}^{-}}$and $\delta^{18} \mathrm{O}-$ $\mathrm{NO}_{3}^{-}$values fall above this mixing line, this could indicate an additional source or the fractionation of nitrate from assimilation or denitrification that would increase the heavy isotope levels, while isotope values below the mixing line could indicate an additional source of nitrate with lighter isotope values, such as from nitrification or fertilizer sources (Wankel et al., 2006).

\subsection{Estuarine net fluxes of nitrogen}

A box model was used to estimate net fluxes of $\mathrm{TN}, \mathrm{NO}_{3}^{-}$, and nitrate isotope loads along the Potomac River estuary using methods modified from Officer (1980), Boynton et al. (1995), Hagy et al. (2000), and Testa et al. (2008), which are widely used methods for tracking nutrient fluxes in estuaries between different salinity zones. First, the Potomac Estuary was divided into six boxes in order to accommodate adequate sampling stations per box, and to evaluate net fluxes at key locations along the estuarine gradient (Fig. 2). Next, due to the Potomac Estuary having a semi-diurnal tidal cycle, where there is movement back and forth across boundaries of the box model, mean monthly freshwater discharge inputs to the first box (USGS, 2014) and interpolated salinity values (measured monthly from surface and bottom waters throughout the system) were used to calculate advective and diffusive exchanges of water and salt between adjacent boxes. Salt balances were then used to compute net exchanges at the bound- 


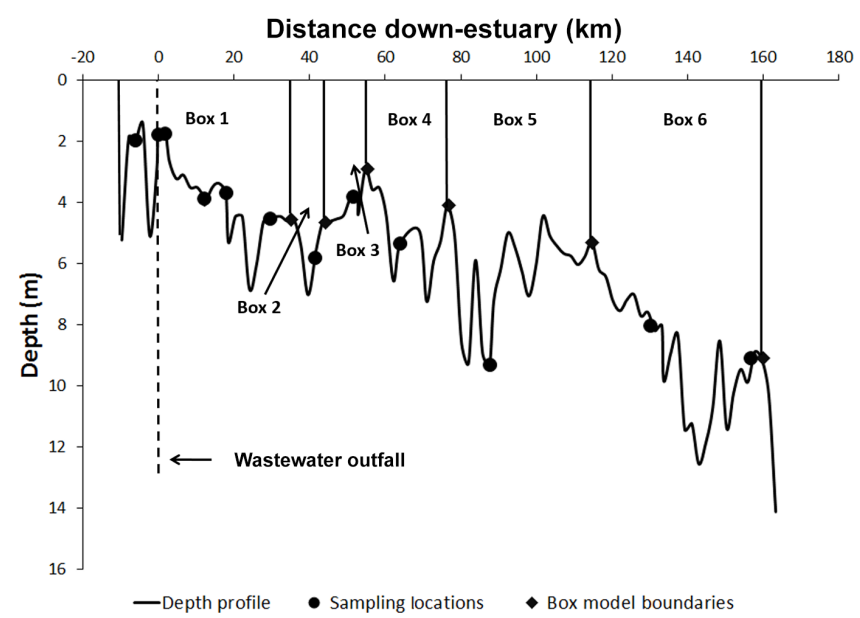

Figure 2. Plot of the Potomac Estuary depth with distance downestuary, with the Blue Plains wastewater treatment plant at distance zero, showing the location of the six boxes used in the box model calculations.

aries of the six model boxes, similar to previous estuarine box model studies (e.g., Boynton et al., 1995; Hagy et al., 2000). Average monthly $\mathrm{TN}, \mathrm{NO}_{3}^{-}$, and $\mathrm{NO}_{3}^{-}$isotope concentrations (collected from the surface and bottom water at each station, except for $\mathrm{NO}_{3}^{-}$isotopes, which were collected from the surface only) were multiplied by net estimated exchange values at the box boundaries and summed to calculate the $\mathrm{N}$ load leaving or entering each box. In order to calculate the loads for $\mathrm{NO}_{3}^{-}$isotopes, the $\delta^{15} \mathrm{~N}_{-} \mathrm{NO}_{3}^{-}$and $\delta^{18} \mathrm{O}-\mathrm{NO}_{3}^{-}$values in per mill $(\% \circ)$ were converted to concentrations $\left(\mu \mathrm{g} \mathrm{L}^{-1}\right)$ by multiplying the $\mathrm{NO}_{3}^{-}$concentration of the sample by $R$, the ratio of the heavy to light isotope $\left({ }^{15} \mathrm{~N} /{ }^{14} \mathrm{~N}\right.$ or $\left.{ }^{18} \mathrm{O} /{ }^{16} \mathrm{O}\right)$. Fluxes were estimated for each month during the sampling period and then averaged to find seasonal estimates of $\mathrm{N}$ fluxes for the Potomac. The box model results were used to compute (1) the total inputs of $\mathrm{N},(2)$ the \% inputs of loads from Blue Plains, (3) the net export of $\mathrm{N}$ to the Chesapeake Bay, (4) the \% of Blue Plains inputs that are exported, (5) the net loss in loads along the estuary, and (6) the contribution of $\mathrm{N}$ loads from the Chesapeake Bay through tidal inflow.

To account for uncertainty in monthly load estimates, error propagation (using standard errors) was used for each of the hydrologic and nutrient inputs to the model. For example, the error in discharge data came from averaging the mean daily discharge for each month, the error in concentrations came from averaging the surface and bottom water concentrations, and the error in $\mathrm{N}$ from atmospheric deposition came from averaging the weakly deposition data for each month. These uncertainties in the inputs to the box model were then propagated for each of the box model calculations, similar to Filoso and Palmer (2011).

Inputs to the box model include total monthly precipitation data based on averaging data from three stations along the Potomac Estuary (precipitation data are from the NOAA
National Centers for Environmental Information, Climate Data Online); monthly estimates of atmospheric deposition for $\mathrm{NH}_{4}^{+}, \mathrm{NO}_{3}^{-}$, and DIN (obtained from the National Atmospheric Deposition Program/National Trends Network); $\mathrm{NO}_{3}^{-}$concentrations and isotope levels in atmospheric deposition (from Buda and DeWalle, 2009, for the nearby central Pennsylvania region for the year 2005, which was a similar year hydrologically); freshwater and $\mathrm{N}$ inputs from the land (from Chesapeake Bay model output from 2005); surface and bottom water nutrient and salinity concentrations (from MD DNR); and inputs from the Blue Plains wastewater treatment plant. Also, while there are no USGS gages located along the Potomac Estuary, there is one USGS gage (USGS 01646580) located about $16 \mathrm{~km}$ up-river from Blue Plains, directly above the estuary (where the hydrodynamics of the river cease being tidally influenced) and this gage was used to account for freshwater inputs into the first box. The model also takes into account water temperature and evaporation.

In the box model we made two assumptions regarding the 14 other WWTPs that are dispersed along the estuary below Blue Plains. All but one of these WWTPs have tertiary treatment (the other has secondary treatment; www.epa.gov/ npdes). These other WWTPs have a combined TN load that is $32 \%$ of the TN load from Blue Plains. While the loads from these WWTPs are indirectly accounted for in the box model due to their impact on the concentrations in the estuarine water, it was not feasible to directly incorporate the loads from each WWTP into the box model estimates and thus there may be some added uncertainties. However, we can first assume that the estimated decline in nitrogen loads from the Blue Plains wastewater treatment plant to the mouth of the Potomac River estuary results in conservative estimates. The additional load from the other WWTPs only adds to the loads estimated further down-estuary, and consequently the measured loss in $\mathrm{N}$ load from the Blue Plains wastewater load down-estuary (the difference between the loads at the mouth and at the head of the estuary) is a conservative estimate because it is less then would be expected, underestimating biological assimilation and removal. Second, for modeling purposes, we also assume here that the loads from the 14 other WWTPs have little effect on the nitrate isotope signal. While $\delta^{15} \mathrm{~N}_{-} \mathrm{NO}_{3}^{-}$and $\delta^{18} \mathrm{O}-\mathrm{NO}_{3}^{-}$isotope values were not measured directly for the 14 other down-estuary wastewater treatment plants, based on the literature, the values for average WWTP nitrate isotopes are typically lower $(\sim 10 \%$ o for $\delta^{15} \mathrm{~N}_{-} \mathrm{NO}_{3}^{-}$and $\sim 0$ for $\delta^{18} \mathrm{O}-\mathrm{NO}_{3}^{-}$) compared to 31.5 for $\delta^{15} \mathrm{~N}-\mathrm{NO}_{3}^{-}$and $11 \% \circ \delta^{18} \mathrm{O}-\mathrm{NO}_{3}^{-}$for Blue Plains (Kendall et al., 2007; Wang et al., 2013; Wankel et al., 2006). As a result, we expected the other WWTPs to have a similar or an even less pronounced wastewater isotope signal compared to Blue Plains, which has biological nitrogen removal (i.e., denitrification is promoted within the Blue Plains WWTP), elevating the $\delta^{15} \mathrm{~N}_{-} \mathrm{NO}_{3}^{-}$and $\delta^{18} \mathrm{O}-\mathrm{NO}_{3}^{-}$isotope values at Blue Plains 
more (Kendall et al., 2007). Consequently, the estimated nitrate loads down-estuary incorporate inputs from Blue Plains and inputs from the other WWTPs. They are considered conservative estimates because the additional WWTPs only add to the TN loads and wastewater $\mathrm{NO}_{3}^{-}$isotope signal, so any decline in an isotope signal that we attribute to Blue Plains would likely be greater if data availability permitted us to specifically parameterize the isotope values for additional WWTP inputs.

Another assumption was made for the box model related to estuarine mixing. Although portions of the lower estuary can be seasonally stratified, we assumed each box to be well mixed vertically as no bottom water isotope values were available to constrain a two-layer box model. This assumption is supported by other bottom water data that are available and by samples taken along the width of the estuary. For example, we have conducted the box model and other analyses with and without bottom water isotope data and found minimal change in results (Fig. S1 in the Supplement). Our measurements of various biogeochemical signatures at the station close to the estuarine turbidity maximum suggests that there is intense mixing at this site, and prior studies have documented extensive mixing in the freshwater tidal portion of the system (Elliott, 1976, 1978; Pritchard, 1956). Also, it can be assumed that, because wastewater effluent inputs are freshwater, much of the effluent plume would likely not sink in the more dense estuarine waters moving up from the bay. Additionally, our box model estimates of net fluxes was compared to a complex, three-dimensional hydrodynamic model (described below) that incorporates stratification, and this comparison provided support for the low impact of assuming mixing in our approach.

Only surface water samples were analyzed for $\delta^{15} \mathrm{~N}^{-\mathrm{NO}_{3}^{-}}$ and $\delta^{18} \mathrm{O}-\mathrm{NO}_{3}^{-}$isotopes, and as a result our box model was not able to directly incorporate the potential impacts of stratification on the estimated flux of $\mathrm{NO}_{3}^{-}$isotopes. However, while seasonal stratification has been found close to the mouth of the Potomac Estuary (Hamdan and Jonas, 2006), using documented nitrate bottom water isotope values from near the mouth of the estuary (Horrigan et al., 1990) we calculate that incorporating bottom water isotope values would have a minimal impact on the flux estimates of our box model, particularly when not including spring 2011 (Fig. S1). But when including spring 2011, and using the reported values of $10 \%$ for bottom water $\delta^{15} \mathrm{~N}^{-\mathrm{NO}_{3}^{-}}$, based on Horrigan et al. (1990), in boxes 5 and 6 , where stratification is most likely, our estimates for the flux of $\delta^{15} \mathrm{~N}^{-\mathrm{NO}_{3}^{-}}$from these boxes increases by $20 \%$ on average, and the net loss in load from box 1 to box 6 increases by $12 \%$ on average. This indicates that our estimates are conservative because, by not using bottom water, we estimate a smaller net loss in $\delta^{15} \mathrm{~N}$ $\mathrm{NO}_{3}^{-}$(Fig. S1).

For the box model we also assumed the estuary to be well mixed laterally. In terms of potential variability for samples taken at different locations along the width of the estuary, for surface water samples, on average, a $6 \pm 3 \%$ difference was found in $\delta^{15} \mathrm{~N}_{-} \mathrm{NO}_{3}^{-}$, a $7 \pm 3 \%$ difference in $\delta^{18} \mathrm{O}-\mathrm{NO}_{3}^{-}$, a $24 \pm 8 \%$ difference in $\mathrm{NO}_{3}^{-}$, and a $15 \pm 3 \%$ difference in $\mathrm{TN}$ (based on samplings that were done at two or more locations along the same longitudinal transect at approximately the same distance down-estuary, but at different locations horizontally at that location). Consequently, the nitrate isotope values and $\mathrm{NO}_{3}^{-}$and $\mathrm{TN}$ concentrations appear to show that the estuary is fairly well mixed laterally.

To assess the accuracy of the box model assumptions and results, estimated net fluxes of total $\mathrm{N}$ were compared to simulation output from the Chesapeake Bay Water Quality Model. This model was developed by the US EPA to aid in efforts to set total maximum daily loads (TMDLs), the maximum amount for each pollutant that can occur, for the Chesapeake Bay (Cerco et al., 2010), and it combines a 3D hydrodynamic model (CH3D) with a water quality model (CE-QUAL-ICM). Simulation output data were available for 1996, 2002, and 2005. We selected a simulation year (2005) because it had similar river discharge conditions to 2010, and compared modeled net fluxes of TN at three boundary locations to estimates at the same (or nearby) box model boundaries.

\subsection{Statistical analyses}

Statistical analyses were performed using the statistical package R (R Development Core Team, 2013). Linear regression was used to test for significant changes in stream chemistry and nitrate isotope data with distance down-estuary. Repeated-measures analysis of variance (ANOVA) was used to test for seasonal differences in nitrate isotopes trends with distance.

\section{Results}

\subsection{Spatial and temporal trends in $\mathbf{N}$ concentrations}

Longitudinal patterns of dissolved inorganic nitrogen (DIN) in the lower Potomac River showed an increase in concentrations near and directly below the Blue Plains wastewater treatment plant and then a steady decline in concentrations down to the Chesapeake Bay (Fig. 3a). The implementation of tertiary treatment in 2000 coincided with a significant drop in annual average DIN concentration directly down-estuary of the Blue Plains WWTP (from $1.7 \pm 0.02$ to $1.3 \pm 0.01 \mathrm{mg} \mathrm{L}^{-1}, p<0.05$; Fig. 3a) when comparing years directly prior (1997-1999) and the years directly after 2000 (2001-2005). However, the impact of the wastewater treatment plant improvements on reducing longitudinal patterns of DIN was only apparent for the first $30 \mathrm{~km}$ down-estuary. After this, both the pre- and post-2000 DIN concentrations overlapped (Fig. 3a). As DIN decreased longitudinally downestuary of the wastewater treatment plant, there was also a 

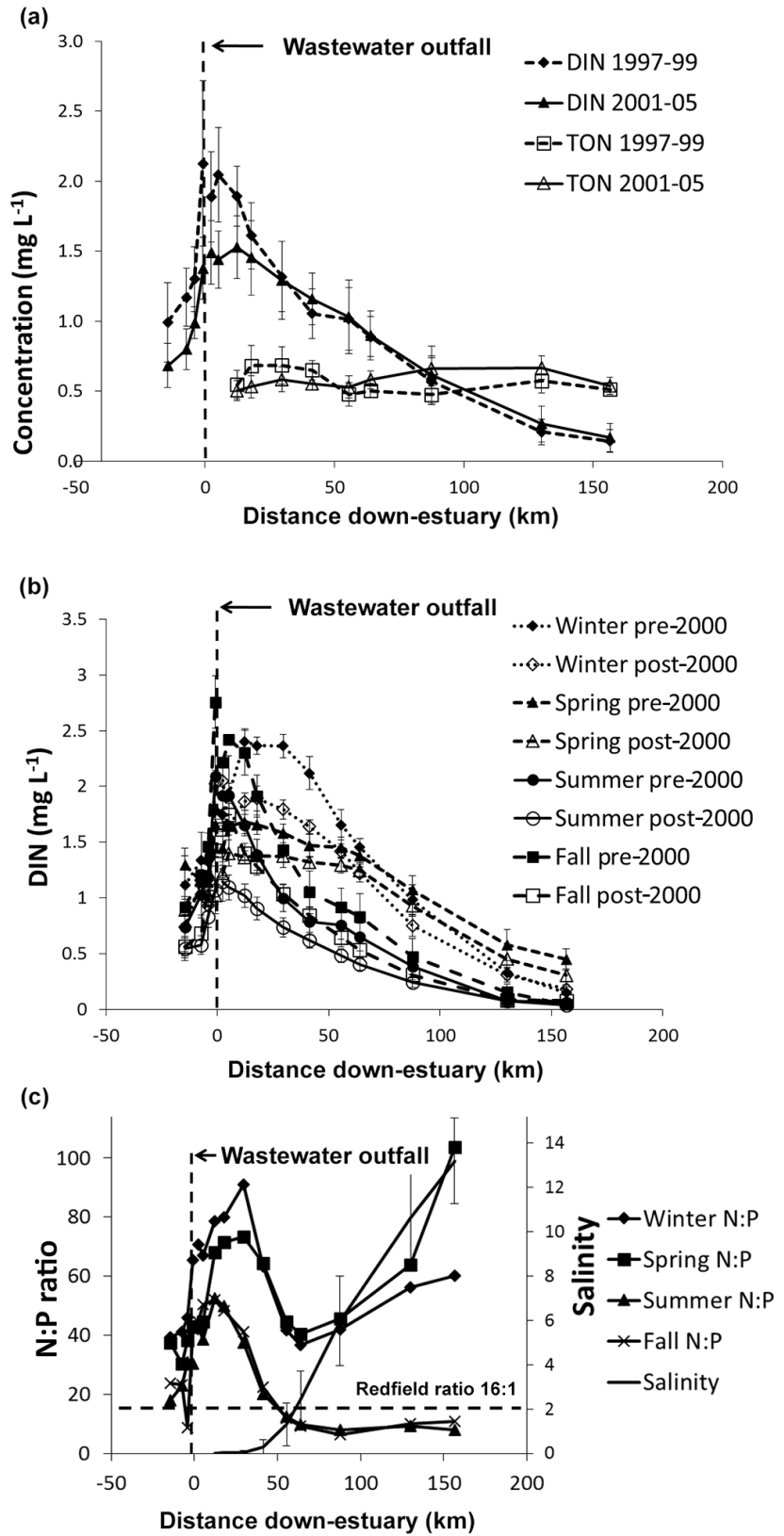

Figure 3. Longitudinal patterns in Potomac River estuary: (a) mean annual dissolved inorganic nitrogen (DIN) and total organic nitrogen (TON) spanning 1997 to 2005, (b) mean seasonal DIN before year 2000 (1994 to 1999), and post-2000 (2001 to 2012), and (c) mean (1994 to 2012) seasonal molar $\mathrm{N}: \mathrm{P}$ ratio (DIN / $\mathrm{PO}_{4}^{-3}$ ), with salinity averaged from all seasons (1984 to 2008). Note: error bars are provided, but SE is relatively small compared to concentrations. Data were obtained from the Maryland DNR and the Chesapeake Bay Program Data Hub.

small but significant increase in total organic nitrogen (TON) after the year 2000 ( $p<0.01$, Fig. 3a), not including the last sample near the mouth of the estuary, which is likely influenced by tidal inflow.

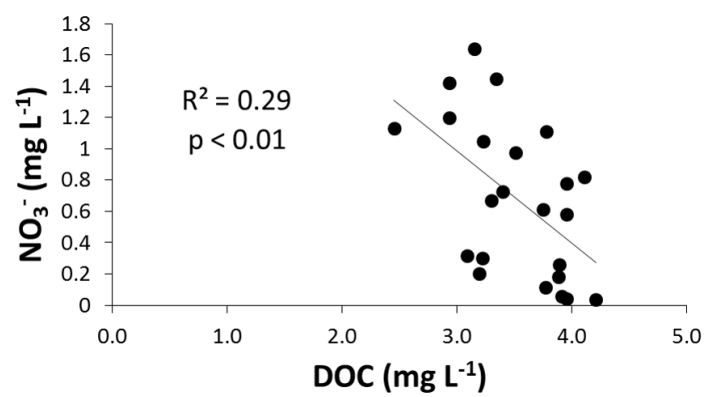

Figure 4. Comparison of $\mathrm{NO}_{3}^{-}$vs. dissolved organic carbon (DOC). Data was obtained from the Maryland DNR and the Chesapeake Bay Program Data Hub for this study period (2010-2012).

There were seasonal variations in DIN concentrations along the Potomac River estuary with the greatest concentrations in the winter and spring (Fig. 3b). There is also a steeper decline in DIN with distance during fall, winter, and summer compared to the spring ( $p<0.05$, Fig. $3 \mathrm{~b})$. The average molar ratio of DIN to $\mathrm{PO}_{4}^{-3}(\mathrm{~N}: \mathrm{P}$ ratio) showed an initial increase, then a decrease as estuarine salinity started to increase (Fig. 3c). During the summer and fall, the $\mathrm{N}: \mathrm{P}$ ratio fell below the Redfield ratio $(16: 1$, the atomic ratio of nitrogen and phosphorus found in oceans and phytoplankton), around $40 \mathrm{~km}$ down-estuary and stayed below 16, which indicated a shift from $\mathrm{P}$ to $\mathrm{N}$ limitation. During the winter and spring, the $\mathrm{N}: \mathrm{P}$ ratio never fell below 16 and increased steadily after $50 \mathrm{~km}$ down-estuary (Fig. 3c). There was also a significant negative relationship between $\mathrm{NO}_{3}^{-}$and DOC concentration during the study period $(p<0.01$, Fig. 4$)$.

\subsection{Spatial and seasonal trends in $\mathrm{NO}_{3}^{-}$isotopes and sources}

During each season, except spring, $\delta^{15} \mathrm{~N}-\mathrm{NO}_{3}^{-}$values increased sharply at the Blue Plains outfall, from $9.3 \pm 1.4 \%$ o up-estuary to $25.7 \pm 2.9 \%$ at the outfall ( $\mathrm{p}<0.05$ ), and then rapidly decreased within $2 \mathrm{~km}$ down-estuary of the Blue Plains WWTP to $15.7 \pm 2.2 \%$ ( $p<0.05$, Fig. 5a). During the summer and fall, the $\delta^{15} \mathrm{~N}-\mathrm{NO}_{3}^{-}$values showed the largest increase near the effluent outfall (except for one very high winter value) and then a significant decrease $(p<0.05)$ with distance down-estuary. There was also a slight increase in $\delta^{15} \mathrm{~N}$ $\mathrm{NO}_{3}^{-}$and $\delta^{18} \mathrm{O}-\mathrm{NO}_{3}^{-}$values from 1 to $6 \mathrm{~km}$ down-estuary (Fig. 5a, b). During the winter and spring, the $\delta^{15} \mathrm{~N}^{-\mathrm{NO}_{3}^{-}}$ and $\delta^{18} \mathrm{O}^{-\mathrm{NO}_{3}^{-}}$values remained relatively constant throughout the estuary, even near Blue Plains (Fig. 5a, b), while during the summer and fall the $\delta^{15} \mathrm{~N}^{-\mathrm{NO}_{3}^{-}}$and $\delta^{18} \mathrm{O}-\mathrm{NO}_{3}^{-}$values steadily declined after $6-10 \mathrm{~km}$ down-estuary (Fig. 5a, b). At the mouth of the estuary, the $\delta^{15} \mathrm{~N}^{-\mathrm{NO}_{3}^{-}}$values for all seasons were roughly equivalent (Fig. 5a). During the summer and fall, the $\delta^{18} \mathrm{O}-\mathrm{NO}_{3}^{-}$values showed a steady decrease after $12 \mathrm{~km}$ down-estuary, while they increased during spring and winter (Fig. 5b). 

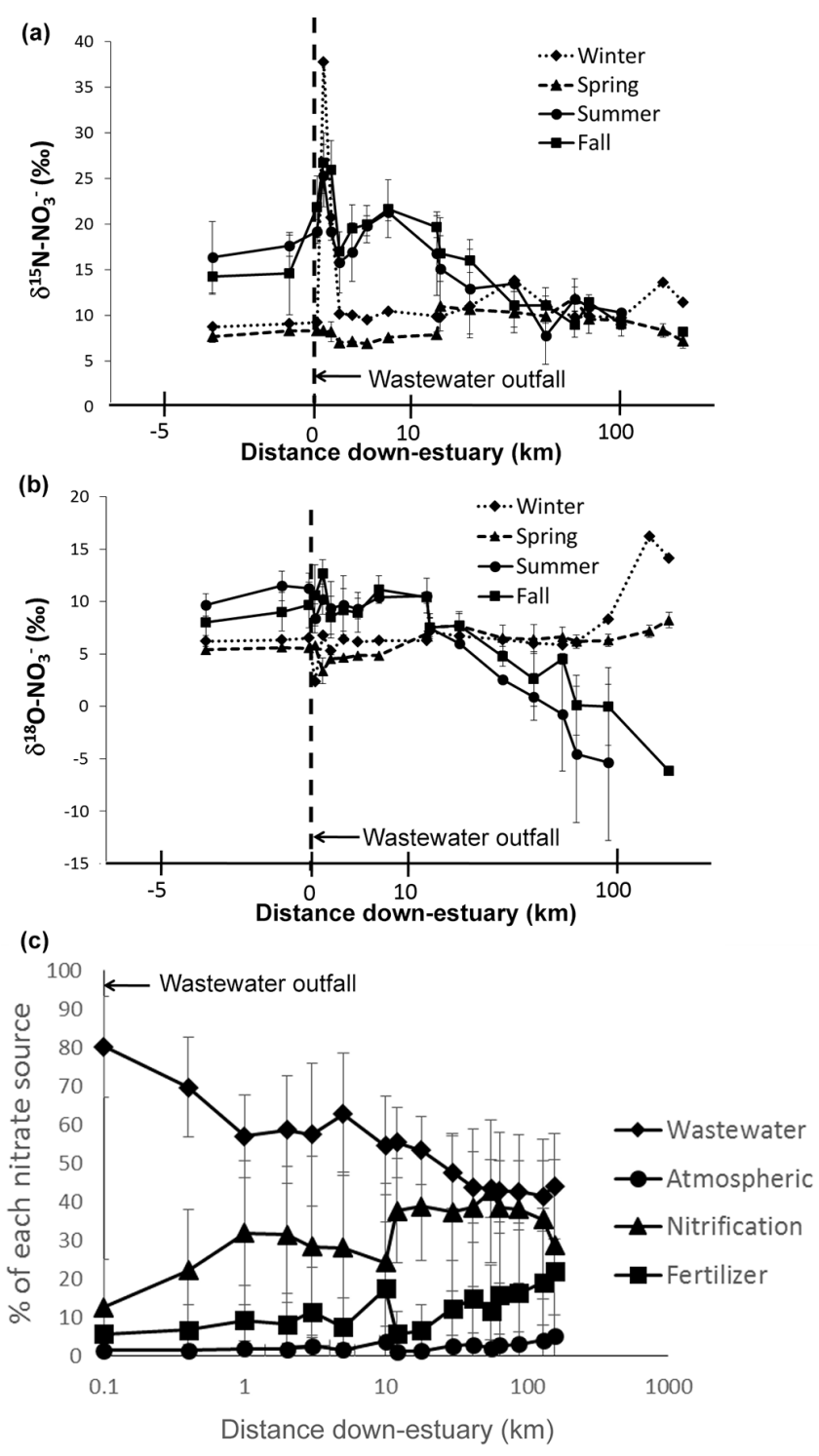

Figure 5. Trends in (a) $\delta^{15} \mathrm{~N}-\mathrm{NO}_{3}^{-}$, (b) $\delta^{18} \mathrm{O}-\mathrm{NO}_{3}^{-}$, and (c) percent contribution of nitrate from wastewater, fertilizer, atmospheric deposition, and nitrification, based on the isotope mixing model, with distance down-estuary from wastewater treatment plant input. Error bars are standard errors of the mean. $N=1$ for winter, $N=3$ for spring and fall, and $N=2$ for summer.

Based on the nitrate isotope mixing model, nitrate contributions from wastewater ranged from $80 \pm 13 \%$ at the wastewater outfall to $57 \pm 11 \%$ within the first $1 \mathrm{~km}$ downestuary. Wastewater nitrate contributions then decreased to $44 \pm 14 \%$ at the confluence of the Potomac River estuary with Chesapeake Bay (Fig. 5c). When we multiply the percent wastewater nitrate by the nitrate loads estimated from the box model for the top and bottom of the estuary (results below), we calculate that there was a $70 \pm 31 \%$ loss in wastewater $\mathrm{NO}_{3}^{-}$along the estuary annually. Nitrate from nitrification (of $\mathrm{N}$ from upriver manure or ammonia fer-
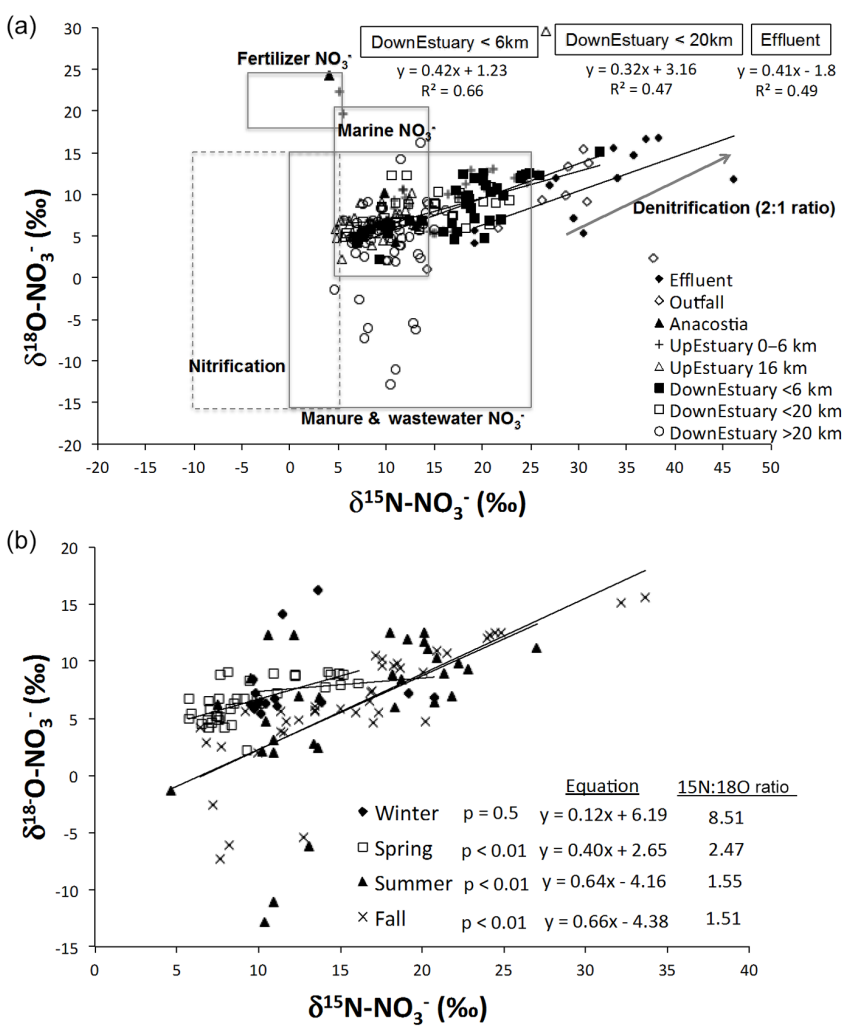

Figure 6. (a) Plot of $\delta^{15} \mathrm{~N}-\mathrm{NO}_{3}^{-}$vs. $\delta^{18} \mathrm{O}-\mathrm{NO}_{3}^{-}$of nitrate from effluent water samples and Potomac River estuary samples, showing samples from different locations along the estuary; the grey arrow indicates the 2:1 relationship characteristic for denitrification. (b) Same plot as (a) but seasonally and without the effluent or wastewater outfall values. Not included in these plots is the box indicating the region where atmospheric nitrate samples generally lie, from -10 to +15 for $\delta^{15} \mathrm{~N}-\mathrm{NO}_{3}^{-}$and from 60 to 100 for $\delta^{18} \mathrm{O}-\mathrm{NO}_{3}^{-}$.

tilizer and also Blue Plains wastewater $\mathrm{N}$ ) increased from $13 \pm 12 \%$ at the wastewater outfall to $29 \pm 22 \%$ at the confluence of the Potomac River estuary with Chesapeake Bay (Fig. 5c). Nitrate from fertilizer increased from $6 \pm 6 \%$ at the wastewater outfall to $22 \pm 22 \%$ at the confluence of the Potomac River estuary with Chesapeake Bay (Fig. 5c). Nitrate from atmospheric deposition changed little along the Potomac Estuary from $1 \pm 1$ at the wastewater outfall to $5 \pm 5$ at the confluence with the Chesapeake Bay (Fig. 5c). At the last two sampling stations near the mouth of the Potomac River estuary, $\mathrm{NO}_{3}^{-}$from fertilizer showed an increase, while $\mathrm{NO}_{3}^{-}$ from nitrification showed a corresponding decline (Fig. 5c).

\section{$3.3 \quad \delta^{15} \mathrm{~N}-\mathrm{NO}_{3}^{-}$and $\delta^{18} \mathrm{O}-\mathrm{NO}_{3}^{-}, \mathrm{NO}_{3}^{-}$concentration, and salinity relationships}

The Blue Plains effluent and Potomac River samples within $20 \mathrm{~km}$ down-estuary of the wastewater treatment plant showed a significant positive relationship between $\delta^{15} \mathrm{~N}$ $\mathrm{NO}_{3}^{-}$and $\delta^{18}{\mathrm{O}-\mathrm{NO}_{3}^{-}}^{-}(p<0.05$; Fig. 6a). When denitrifica- 
tion and biotic uptake occurs, plotting $\delta^{15} \mathrm{~N}-\mathrm{NO}_{3}^{-}$vs. $\delta^{18} \mathrm{O}-$ $\mathrm{NO}_{3}^{-}$shows a $2: 1$ relationship (Kendall et al., 2007). The Blue Plains effluent samples showed approximately a 2.4 to 1 relationship. The samples within $20 \mathrm{~km}$ down-estuary showed a $3: 1$ ratio (Fig. 6a). The nitrate samples within the first $6 \mathrm{~km}$ showed a 2.4 to 1 relationship (Fig. 6a). There were also seasonal differences in the relationship between $\delta^{15} \mathrm{~N}$ $\mathrm{NO}_{3}^{-}$and $\delta^{18} \mathrm{O}-\mathrm{NO}_{3}^{-}$(Fig. 6b); spring, summer, and fall were characterized by close to a $2: 1$ relationship between $\delta^{15} \mathrm{~N}$ $\mathrm{NO}_{3}^{-}$vs. $\delta^{18} \mathrm{O}-\mathrm{NO}_{3}^{-}$, while winter showed a $\sim 8: 1$ relationship.

Because salinity is a conservative tracer, plots of salinity vs. $\mathrm{NO}_{3}^{-}, \delta^{15} \mathrm{~N}_{-} \mathrm{NO}_{3}^{-}$, and $\delta^{18} \mathrm{O}-\mathrm{NO}_{3}^{-}$can indicate effects of mixing between water at the tidal freshwater section with water from the mesohaline section of the Potomac River estuary. Deviations from the mixing lines can indicate additional sources or biological transformations (Middelburg and Nieuwenhuize, 2000; Wankel et al., 2006). Surface water $\mathrm{NO}_{3}^{-}$concentrations and nitrate isotopes fell on (for $\delta^{18} \mathrm{O}$ $\mathrm{NO}_{3}^{-}$) or slightly below mixing line (for $\delta^{15} \mathrm{~N}-\mathrm{NO}_{3}^{-}$) during the spring (Fig. 7a,b,c), which indicated mostly conservative

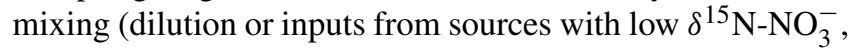
like nitrification). But during the summer and fall, the $\mathrm{NO}_{3}^{-}$ concentration and isotope values fell well below the mixing lines. During the winter, the values fell both above and below the mixing line (Fig. 7a, b, c), which indicated nonconservative mixing.

\subsection{Spatial and seasonal trends in $\mathrm{N}$ loads}

Our comparisons of box model net exchange estimates with simulation output provided by the Chesapeake Bay Program eutrophication model ("Bay Model") revealed similar TN loads between our results and the Bay Model in the winter, spring, and fall, with the largest differences in the models evident in the summer months at the boundary location where tidal fresh transitions to oligohaline conditions and at the mouth of the estuary (Table S3 and Figs. 8 and 9). Even so, these differences are smaller than a factor of 2 for winter and spring and for most of the summer and fall. Despite the assumption of complete mixing in our box model, this is a good agreement considering the simplification of hydrodynamics inherent to a box modeling approach when compared to the highly constrained CH3D hydrodynamic modeling platform (Cerco et al., 2010). The Potomac Estuary is well mixed along two-thirds of its length, and this likely contributes to our success in applying a single-layer box model to this system. The box model also permitted estimates of TN loads at smaller spatial scales than the three boundaries available from the Chesapeake Bay Program, which could enable a better interpretation of where Blue Plains effluent was subject to transformations in the oligohaline portion of the estuary (Fig. 8). The caveat here is that box-modeled summer loads should be interpreted with caution because they show the greatest differences from the CH3D model.
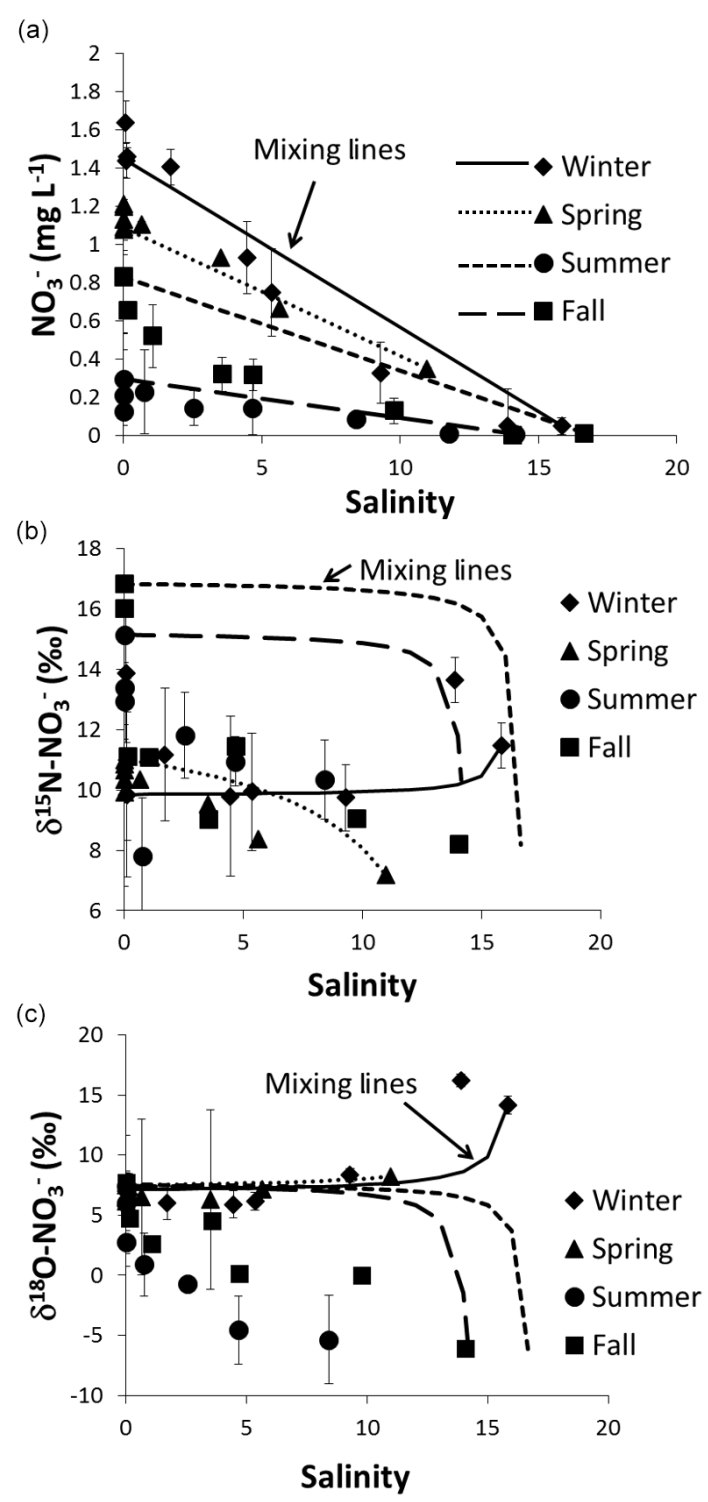

Figure 7. Comparison of salinity vs. (a) $\mathrm{NO}_{3}^{-}$, (b) $\delta^{15} \mathrm{~N}-\mathrm{NO}_{3}^{-}$, and (c) $\delta^{18} \mathrm{O}-\mathrm{NO}_{3}^{-}$. Mixing lines connect the mean $\mathrm{NO}_{3}^{-}$concentration or isotope values at the lowest and highest salinity values. Error bars are standard errors of the mean. For (a), $N=3$ for all seasons; for (b) and (c), $N=1$ for winter, $\mathrm{N}=3$ for spring and fall, and $\mathrm{N}=2$ for summer. Mixing line equations for $\mathrm{NO}_{3}^{-}$concentrations and isotopes were obtained from Middelburg and Nieuwenhuize (2001). $\mathrm{NO}_{3}^{-}$data were obtained from the Maryland DNR and the Chesapeake Bay Program Data Hub, covering spring 2010 to spring 2011, the same dates as the $\mathrm{NO}_{3}^{-}$isotope data.

Results of the box model indicate that an annual average of $8.4 \times 10^{6} \pm 4.8 \times 10^{6} \mathrm{~kg} \mathrm{yr}^{-1}$ of TN are exported to the Bay and the net loss in load for TN along the estuary (from Blue Plains to the mouth of the estuary), attributed to assimilation, burial, and denitrification, was $9.1 \times 10^{6} \pm 5.1 \times 10^{6} \mathrm{~kg} \mathrm{yr}^{-1}$ of $\mathrm{TN}$. Using an $\mathrm{N}$ burial rate of $2.49 \times 10^{6} \pm 3.1 \times 10^{5} \mathrm{~kg} \mathrm{yr}^{-1}$ (Harris, unpublished 
Table 1. Seasonal comparison of $\mathrm{N}$ inputs, exports, and losses along the Potomac River estuary (mean \pm standard error).

\begin{tabular}{|c|c|c|c|c|c|c|c|c|c|c|}
\hline & Nutrient & $\begin{array}{r}\text { Total inputs } \\
\left(\mathrm{kg} \mathrm{day}^{-1}\right)\end{array}$ & $\begin{array}{r}\% \text { of } \\
\text { Inputs from } \\
\text { Blue Plains* }\end{array}$ & $\begin{array}{l}\text { Net export } \\
\left(\mathrm{kg} \mathrm{day}^{-1}\right)\end{array}$ & $\begin{array}{r}\% \text { of Blue } \\
\text { Plains Inputs } \\
\text { Exported }\end{array}$ & $\begin{array}{r}\text { Net loss in } \\
\text { load along estuary, } \\
\text { box } 1 \text { to } 6 \\
\left(\mathrm{~kg} \mathrm{day}^{-1}\right)\end{array}$ & $\begin{array}{r}\% \text { Net loss in } \\
\text { load along estuary, } \\
\text { in box } 1 \text { to } 6\end{array}$ & $\begin{array}{r}\text { Net loss in load } \\
\text { along estuary, } \\
\text { box } 1 \text { to } 5 \\
\left(\mathrm{~kg} \mathrm{day}^{-1}\right)\end{array}$ & $\begin{array}{r}\% \text { Net loss in } \\
\text { load along estuary, } \\
\text { box } 1 \text { to } 5\end{array}$ & $\begin{array}{r}\text { Net loads from } \\
\text { bay to estuary } \\
\left(\mathrm{kg} \mathrm{day}^{-1}\right)\end{array}$ \\
\hline Winter & $\mathrm{TN}$ & $49150 \pm 30323$ & $10 \pm 13$ & $19844 \pm 13728$ & $3.7 \pm \mathrm{NA}$ & $27369 \pm 14597$ & $54 \pm 40$ & $16426 \pm 9509$ & $28 \pm 25$ & $473 \pm 414$ \\
\hline Spring & $\mathrm{TN}$ & $135317 \pm 14614$ & $8 \pm 0.8$ & $68431 \pm 48060$ & $71 \pm 20$ & $49672 \pm 52116$ & $36 \pm 43$ & $29515 \pm 32908$ & $26 \pm 21$ & $-127 \pm 480$ \\
\hline Summer & $\mathrm{TN}$ & $13888 \pm 596$ & $38 \pm 3$ & $4853 \pm 8326$ & $19 \pm 11$ & $7155 \pm 8370$ & $75 \pm 75$ & $5739 \pm 1832$ & $44 \pm 21$ & $380 \pm 164$ \\
\hline Fall & $\mathrm{TN}$ & $15334 \pm 3700$ & $47 \pm 13$ & $-1613 \pm 12124$ & $18 \pm 10$ & $15364 \pm 12548$ & $112 \pm 95$ & $4140 \pm 6607$ & $30 \pm 43$ & $264 \pm 290$ \\
\hline Winter & $\mathrm{NO}_{3}^{-}$ & $37749 \pm 23574$ & $5.7 \pm 4.6$ & $2080 \pm 6235$ & $3 \pm \mathrm{NA}$ & $31791 \pm 7417$ & $93 \pm 29$ & $26299 \pm 10069$ & $74 \pm 33$ & $32 \pm 58$ \\
\hline Spring & $\mathrm{NO}_{3}^{-}$ & $95395 \pm 10416$ & $7.4 \pm 0.6$ & $30039 \pm 161747$ & $52 \pm 70$ & $40206 \pm 161977$ & $60 \pm 187$ & $30998 \pm 26791$ & $46 \pm 34$ & $8 \pm 109$ \\
\hline Summer & $\mathrm{NO}_{3}^{-}$ & $7066 \pm 364$ & $49 \pm 6.3$ & $105 \pm 4130$ & $17 \pm 2$ & $5166 \pm 4143$ & $96 \pm 141$ & $4223 \pm 763$ & $77 \pm 19$ & $11 \pm 10$ \\
\hline Fall & $\mathrm{NO}_{3}^{-\frac{5}{2}}$ & $10526 \pm 3006$ & $53 \pm 18.2$ & $-204 \pm 6278$ & $13 \pm 35$ & $7291 \pm 6812$ & $108 \pm 181$ & $5637 \pm 6817$ & $85 \pm 122$ & $13 \pm 35$ \\
\hline Winter & $\delta^{15} \mathrm{~N}-\mathrm{NO}_{3}^{-}$ & $130 \pm 10$ & $4 \pm 0.4$ & $4 \pm \mathrm{NA}$ & $2.7 \pm \mathrm{NA}$ & $130 \pm N A$ & $97 \pm N A$ & $77 \pm \mathrm{NA}$ & $68 \pm N A$ & $86 \pm N A$ \\
\hline Spring & $\delta^{15} \mathrm{~N}-\mathrm{NO}_{3}^{-}$ & $374 \pm 3$ & $7 \pm 0.1$ & $170 \pm 547$ & $52 \pm 136$ & $88 \pm 547$ & $48 \pm 136$ & $42 \pm 71$ & $26 \pm 31$ & $-412 \pm 1471$ \\
\hline Summer & $\delta^{15} \mathrm{~N}-\mathrm{NO}_{3}^{-}$ & $30 \pm 1$ & $53 \pm 1.6$ & $5 \pm 1$ & $17 \pm 3$ & $27 \pm 1$ & $83 \pm 3$ & $18 \pm 1$ & $83 \pm 3$ & NA \\
\hline Fall & $\delta^{15} \mathrm{~N}-\mathrm{NO}_{3}^{-\frac{3}{3}}$ & $40 \pm 5$ & $55 \pm 5.8$ & $7 \pm 8$ & $13 \pm 68$ & $26 \pm 8$ & $87 \pm 105$ & $26 \pm 13$ & $87 \pm 105$ & NA \\
\hline
\end{tabular}

Table 2. Comparison of mean ( \pm standard error) seasonal discharge and residence time within the Potomac River estuary.

\begin{tabular}{lrr}
\hline & $\begin{array}{r}\text { Mean discharge } \\
\left(\mathrm{m}^{3} \mathrm{~s}^{-1}\right)\end{array}$ & $\begin{array}{r}\text { Mean residence } \\
\text { time (days) }\end{array}$ \\
\hline Winter & $187 \pm 60$ & $26 \pm 18$ \\
Spring & $545 \pm 214$ & $57 \pm 36$ \\
Summer & $81 \pm 29$ & $129 \pm 85$ \\
Fall & $81 \pm 27$ & $196 \pm 102$ \\
\hline
\end{tabular}

Note: data are based on discharge and box model results for the period from April 2010 to March 2011.

data), a denitrification rate of $6.17 \times 10^{6} \pm 8.3 \times 10^{4} \mathrm{~kg} \mathrm{yr}^{-1}$ (Cornwell et al., 2016) and a fisheries yield rate of $0.82 \times 10^{6} \mathrm{~kg} \mathrm{yr}^{-1}$ (Boynton et al., 1995), we see that our box model estimate is nearly balanced by independently estimated values for these loss terms. On a mean annual basis, denitrification accounts for about $68 \pm 1 \%$ of the loss in $\mathrm{TN}$, burial is estimated to account for $27 \pm 3 \%$ of the loss in $\mathrm{TN}$, and assimilation into fisheries accounts for approximately $9 \%$ of loss in TN load along the Potomac Estuary.

The net load $\left(\mathrm{kg} \mathrm{day}^{-1}\right)$ of $\mathrm{TN}, \mathrm{NO}_{3}^{-}$, and $\delta^{15} \mathrm{~N}-\mathrm{NO}_{3}^{-}$ decreased down-estuary during each season (Fig. 10a-c, $p<0.05$ for winter and spring and $p<0.1$ for summer and fall). $\mathrm{N}$ loads were highest along the estuary during spring and winter (Fig. 10), and there was a greater decline in TN loads on average from box 1 to box 6 during winter and spring (a loss of $\sim 27000 \pm 15000$ and $50000 \pm 52000 \mathrm{~kg} \mathrm{day}^{-1}$, respectively; Table 1) compared to summer and fall (a loss of $\sim 7000 \pm 8000$ and $15000 \pm 13000 \mathrm{~kg} \mathrm{day}^{-1}$, respectively). However, the summer and fall months showed a greater percent decline in TN ( $75 \pm 75$ and $112 \pm 95 \%$, respectively) compared to winter and spring ( $54 \pm 40$ and $36 \pm 43 \%$, respectively). The relatively high errors are primarily from the larger uncertainty found in the last box, at the mouth of the estuary, due to the larger size of this box and greater uncertainty in fluxes at the mouth of the estuary; the uncertainties are much smaller fur- ther up-estuary (See Fig. 10a). $\mathrm{NO}_{3}^{-}$and $\delta^{15} \mathrm{~N}-\mathrm{NO}_{3}^{-}$follow the same seasonal patterns as TN. Also, winter, along with summer and fall, showed a greater percent decline in $\mathrm{NO}_{3}^{-}$ and $\mathrm{NO}_{3}^{-}$isotope loads compared to spring (Table 1).

The percent contribution of $\mathrm{TN}$ inputs from the Blue Plains wastewater treatment plant to the main stem of the Chesapeake Bay ranged from 8 to $47 \%$ (Table 1). The contribution was significantly lower during the winter and spring ( $10 \pm 13$ and $8 \pm 1 \%$, respectively) compared to summer and fall (38 \pm 3 and $47 \pm 13 \%$, respectively, Table 1), when TN fluxes from all sources are relatively low. The percent of Blue Plains wastewater TN inputs that are exported to the Chesapeake Bay ranged from $<4$ to $71 \%$, and they were highest in the spring $(71 \pm 20 \%$, Table 1$)$, with an annual average of $28 \pm 6 \%$ of blue plains TN exported from the estuary. There were also $\mathrm{N}$ inputs to the Potomac river-estuarine continuum from the Chesapeake Bay during each season, except spring, due to higher flows (Tables 1 and 2) because flow in spring was too high to allow the inputs from the Bay that occurred in the other seasons. $\mathrm{NO}_{3}^{-}$and $\delta^{15} \mathrm{~N}_{-} \mathrm{NO}_{3}^{-}$follow the same seasonal patterns as $\mathrm{TN}$, showing the greatest percentage of inputs from Blue Plains exported during the spring.

\section{Discussion}

While coastal urbanization can have a major impact on water quality in receiving waters, the results of this study suggest that rivers and estuaries also show a large capacity to transform and bury anthropogenic N. In particular, our results indicate that up to $96 \%$ of inputs of $\mathrm{N}$ from the Washington D.C. Blue Plains wastewater treatment plant were removed via burial or denitrification along the Potomac riverestuarine continuum, depending on the season (Table 1). Recent work shows that urban watersheds and river networks can also be "transformers" of nitrogen across similar broad spatial scales, which impacts downstream coastal water quality (Kaushal et al., 2014a). Similar to our results, previous studies have shown that estuaries can transform and re- 

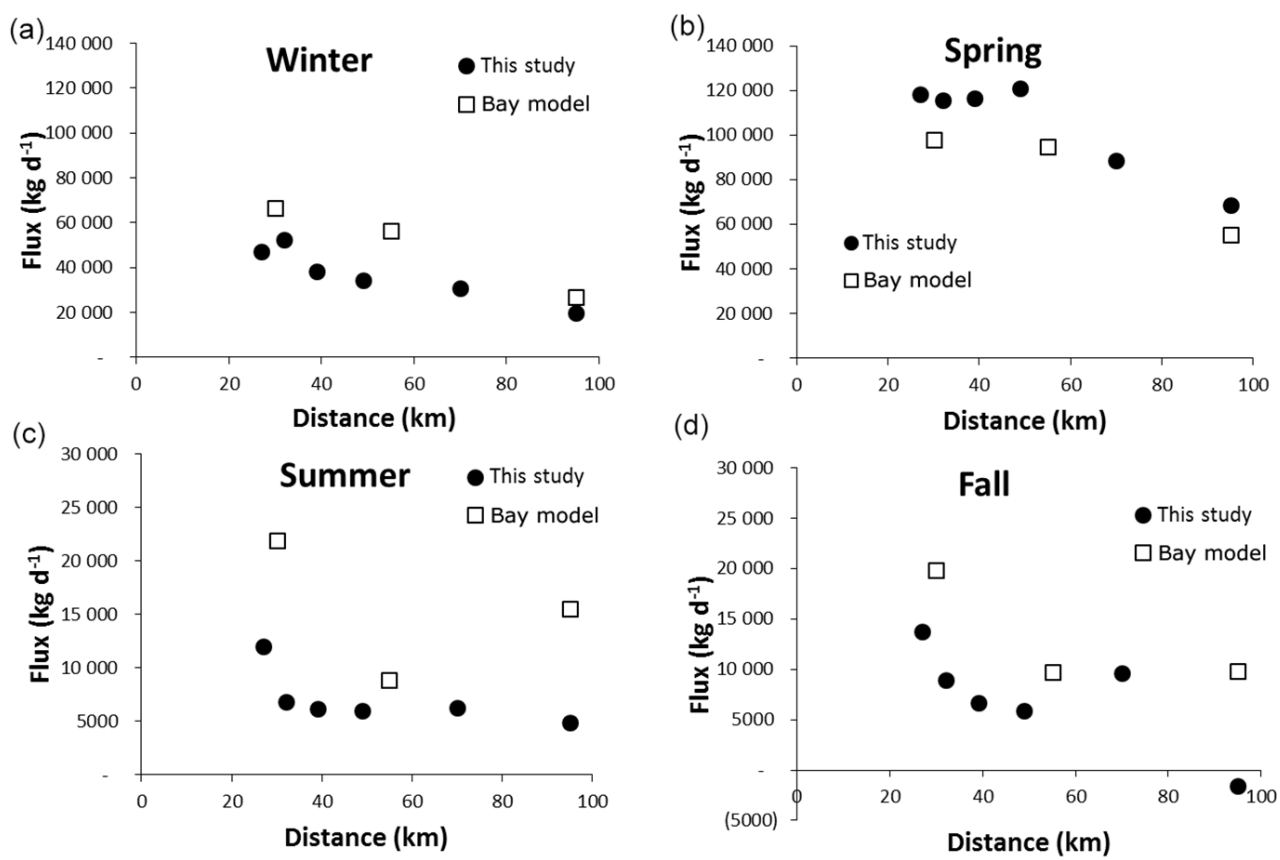

Figure 8. Comparing the TN fluxes along the Potomac River estuary estimated from the box model used in this study and from the results from the Chesapeake Bay nutrient model.

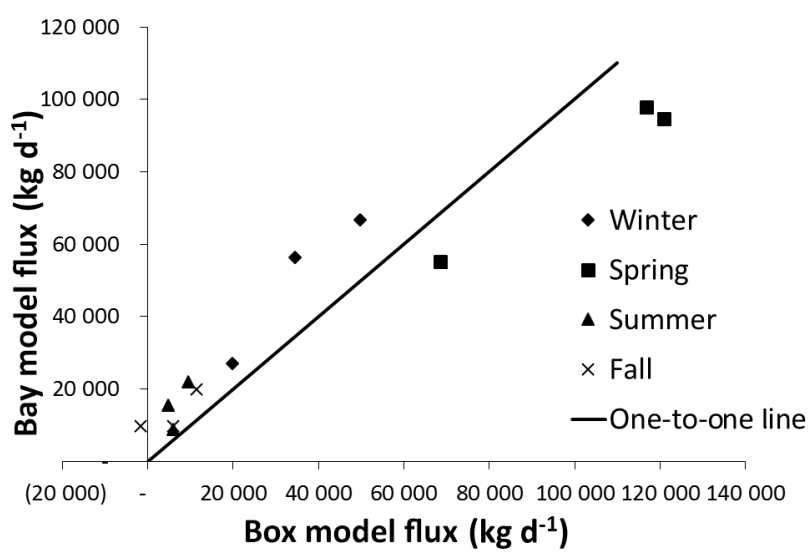

Figure 9. Correlation between the fluxes estimated from the box model used in this study and the Chesapeake Bay nutrient model.

move wastewater inputs of nitrogen through denitrification (e.g., Billen et al., 1985). Our work characterized how the river-estuarine continuum transforms the sources, amounts, and forms of nitrogen transported to the Chesapeake Bay. $\mathrm{N}$ sources varied in response to transformation across seasons and hydrologic conditions with important implications for anticipating changes in coastal nitrogen pollution in response to future climate change. This is particularly significant, given long-term increases in water temperatures of major rivers and increased frequency and magnitude of droughts and floods in this region and elsewhere (e.g., Kaushal et al., 2010a, 2014b).

\subsection{Spatial and temporal trends in $\mathrm{N}$ concentrations and loads}

The decrease in DIN concentrations with distance downestuary is largely from denitrification, assimilation, and burial, as indicated by the inverse relationship between $\mathrm{NO}_{3}^{-}$ concentrations and DOC and TON concentrations, the $\mathrm{NO}_{3}^{-}$ isotope data, and $\mathrm{N}$ mass balance data. Dilution from tidal marine waters plays a minor role in the decrease in DIN and the incoming tidal waters may even contribute to DIN as suggested by the decrease in DIN slope after $130 \mathrm{~km}$ downestuary (Boynton et al., 1995), depending on the season. The installation of tertiary wastewater treatment technology at Blue Plains in the year 2000 showed a significant drop in DIN concentrations within $20-30 \mathrm{~km}$ of Blue Plains. However, the DIN concentrations below $30 \mathrm{~km}$ down-estuary were approximately the same based on an annual average, before and after the year 2000. One explanation is that the dissolved wastewater $\mathrm{N}$ is completely assimilated into particulate organic matter, supported by the inverse $\mathrm{NO}_{3}^{-}$vs. TON or DOC relationships (Figs. 3a and 4), or removed by denitrification (as suggested by the isotope data) within the first $10 \mathrm{~km}$ down-estuary, and thus the majority of DIN below $30 \mathrm{~km}$ is from other inputs than the Blue Plains wastewater treatment plant. For example, there are 14 other smaller wastewater treatment plants along the Potomac River estuary, which contribute a total of about $1.02 \times 10^{9} \mathrm{Lday}^{-1}$ (almost as much as the amount Blue Plains contributes) and they could offset further decreases in $\mathrm{NO}_{3}^{-}$concentrations down-estuary. Also, 

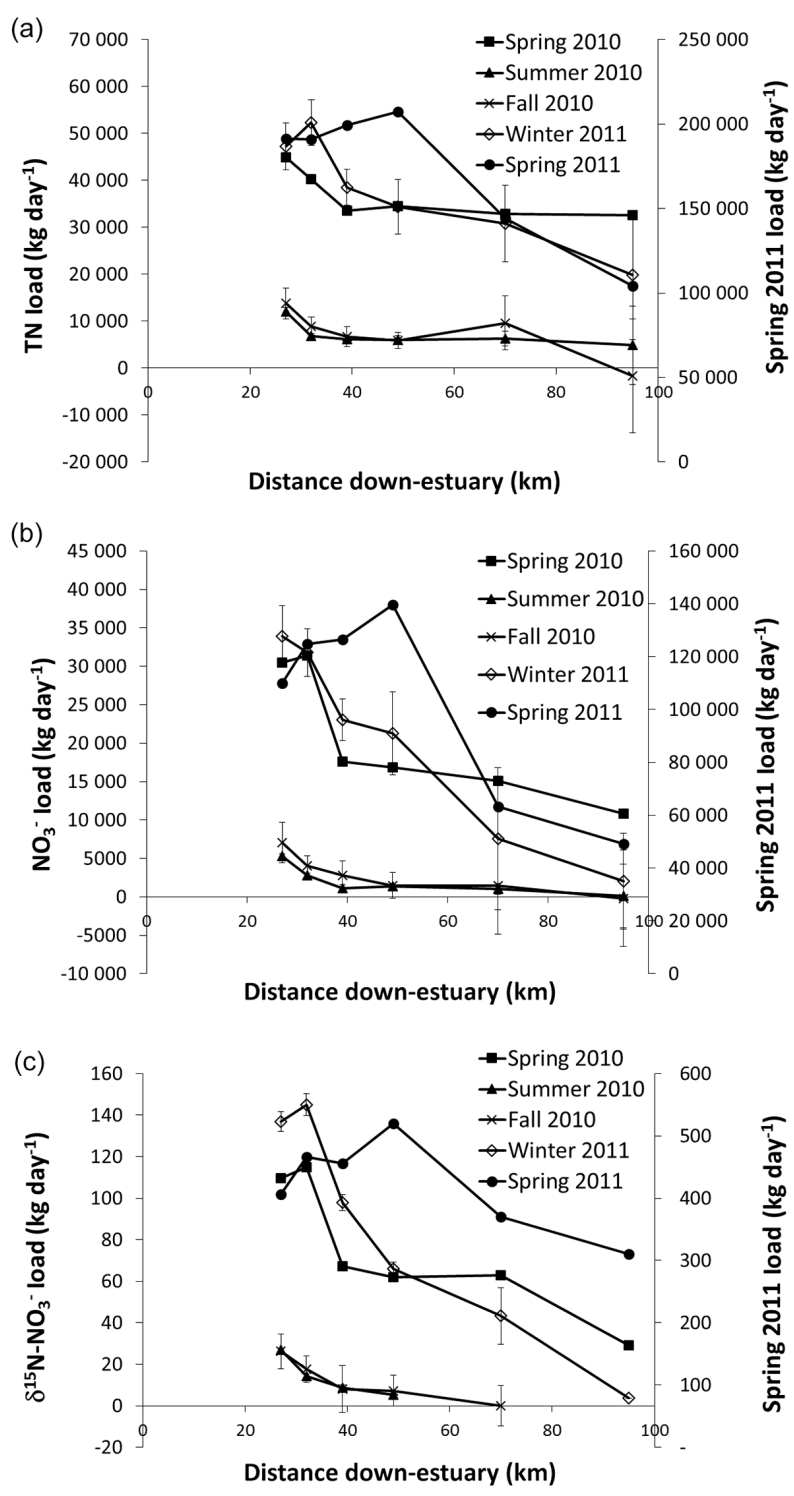

Figure 10. Seasonal box model results showing how (a) TN, (b) $\mathrm{NO}_{3}^{-}$, and (c) $\delta^{15} \mathrm{~N}-\mathrm{NO}_{3}^{-}$loads vary down-estuary. Error bars are standard errors of the mean. For panels (a) and (b), $N=3$ for all seasons. For (c), $N=1$ for winter, $N=3$ for spring and fall, and $N=2$ for summer. TN and $\mathrm{NO}_{3}^{-}$data were obtained from the Maryland DNR and the Chesapeake Bay Program Data Hub.

our isotope mixing model data show that nitrification (likely of upriver manure or ammonia fertilizer inputs) and fertilizer are important sources further down-estuary, and $42 \%$ of the land use along the Potomac Estuary is agriculture (Karrh et al., 2007b). A second explanation could be related to a change in $\mathrm{N}: \mathrm{P}$ ratio with distance down-estuary. Specifically, there was a rise in estuarine salinity around 30 to $50 \mathrm{~km}$ down-estuary and a coinciding increase in dissolved $\mathrm{PO}_{4}^{-3}$ concentration (typical of the estuarine salinity gradient; Jordan et al., 2008). When the $\mathrm{N}: \mathrm{P}$ ratio fell below the Redfield ratio of $16: 1$, the estuary could shift from $\mathrm{P}$ limitation to $\mathrm{N}$ limitation (Fisher et al., 1999). The potential shift from $\mathrm{P}$ to $\mathrm{N}$ limitation occurred 40-50 km down-estuary, around the estuarine turbidity maximum, which is associated with higher estuarine bacterial productivity (Crump and Baross, 1996), and may be driving DIN removal further down-estuary.

Mass balance indicates that $\mathrm{TN}$ and $\mathrm{NO}_{3}^{-}$loads decreased down-estuary each season (despite inputs from the 14 other wastewater treatment plants down-estuary). The $8.4 \times 10^{6} \pm 4.8 \times 10^{6} \mathrm{~kg} \mathrm{yr}^{-1}$ of $\mathrm{TN}$ exported to the Bay annually is close to the $14.1 \times 10^{6} \mathrm{~kg} \mathrm{yr}^{-1}$ estimated by Boynton et al. (1995) for the lower Potomac Estuary. The net loss in load for TN along the estuary $\left(9.1 \times 10^{6} \pm 5.1 \times 10^{6} \mathrm{~kg} \mathrm{yr}^{-1}\right)$, attributed to burial and denitrification, was also similar to the sum of the burial and denitrification rates estimated by Boynton et al. (1995) for the lower Potomac $\left(13.3 \times 10^{6} \mathrm{~kg} \mathrm{yr}^{-1}\right.$ of TN). Also, our comparison of net losses in $\mathrm{TN}$ along the estuary with independent estimates of burial (Harris, unpublished data), denitrification rate (Cornwell et al., 2016), and assimilation (Boynton et al., 1995) closely align with our estimate for the net loss in load for TN along the estuary. The large loss in $\mathrm{TN}$ load attributed to denitrification $(68 \pm 1 \%)$ is supported by the $\mathrm{NO}_{3}^{-}$isotope data indicating that there was likely denitrification (and assimilation) of $\mathrm{NO}_{3}^{-}$, particularly within $6 \mathrm{~km}$ down-estuary from the Blue Plains wastewater treatment plant. Over seasonal timescales, there was a greater percent decline in TN loading during summer and fall, likely due to warmer temperatures and increased biological transformation (attributable to high rates of phytoplankton uptake and detrital deposition; Eyre and Ferguson, 2005; Gillooly et al., 2001; Harris and Brush, 2012; Nowicki, 1994), which suggested that the urban river-estuarine continuum may be more efficient at removing TN during the summer and fall. Compared to summer and fall, winter also had a relatively high percent decline in $\mathrm{NO}_{3}^{-}$loads possibly driven by the higher concentrations typically found in winter months, which could result in quicker assimilation through first-order reaction rate kinetics (Betlach and Tiedje, 1981). Since there was no evidence for denitrification during the winter, burial could also be a mechanism for the relatively high decline in winter months, which is typical of higher flows (Boynton et al., 1995; Milliman et al., 1985; Sanford et al., 2001). However, more work is necessary to evaluate the fate of nitrate using ecosystem process-level measurements.

The higher exports of $\mathrm{TN}$ and $\mathrm{NO}_{3}^{-}$to Chesapeake Bay during the winter and spring are due to greater $\mathrm{N}$ inputs from the upper and lower watershed and/or greater flow rates. The proportion of $\mathrm{N}$ exports attributed to Blue Plains wastewater treatment plant was the highest in the spring, likely due to shorter water residence times (Table 2), resulting in less time for biological uptake, removal, or burial of $\mathrm{N}$. The greater decline in $\mathrm{N}$ loads during the spring, however, may be attributed to multiple factors, such as greater $\mathrm{N}$ loads being imported from the upper estuary and higher concentrations, compared 
to summer and fall (Table 1) and thus driving greater losses (from burial and denitrification) due to first-order reaction rate kinetics (Betlach and Tiedje, 1981) similar to winter (described above), stratification that is characteristic of higher flows (Boesch et al., 2001), and increased burial rates due to greater sediment loads during higher flows (Milliman et al., 1985; Sanford et al., 2001). As mentioned previously, more work is necessary regarding linking ecosystem processes and microbial dynamics with the fate of nitrate in the estuary. Nonetheless, the decline in $\mathrm{TN}$ and $\mathrm{NO}_{3}^{-}$loads down-estuary each season provide strong evidence for the transformation and retention of $\mathrm{N}$ along estuaries.

\subsection{Spatial trends in $\mathrm{NO}_{3}^{-}$sources and role of denitrification, assimilation, and nitrification}

The Potomac River estuary was a transformer of wastewater $\mathrm{N}$ inputs from the Washington D.C. metropolitan area to its confluence with Chesapeake Bay. The values for $\delta^{15} \mathrm{~N}$ $\mathrm{NO}_{3}^{-}$above the wastewater treatment plant were relatively high, suggesting upriver sources may primarily be from animal waste (Burns et al., 2009; Kaushal et al., 2011; Kendall et al., 2007). This is consistent with a previous study which found that $43 \%$ of $\mathrm{N}$ inputs to the upper Potomac River are from manure (Jaworski et al., 1992), while the lower Potomac River has more fertilizer and fewer combined animal feeding operations (CAFOs; US EPA, 2016). Effluent inputs from the Blue Plains wastewater treatment plant significantly increased the $\delta^{15} \mathrm{~N}-\mathrm{NO}_{3}^{-}$values even further, yet this $\mathrm{NO}_{3}^{-}$ signal from wastewater disappeared after $20-30 \mathrm{~km}$ downestuary. The increase in $\delta^{15} \mathrm{~N}-\mathrm{NO}_{3}^{-}$and $\delta^{18} \mathrm{O}-\mathrm{NO}_{3}^{-}$values within the first 1 to $6 \mathrm{~km}$ down-estuary suggests denitrification or assimilation of nitrate, due to the lighter $\delta^{14} \mathrm{~N}$ $\mathrm{NO}_{3}^{-}$and $\delta^{16} \mathrm{O}-\mathrm{NO}_{3}^{-}$isotopes being preferentially denitrified or assimilated and leaving behind the heavier nitrate isotopes (Granger et al., 2004, 2008; Kendall et al., 2007). But the gradual decline in both $\delta^{15} \mathrm{~N}-\mathrm{NO}_{3}^{-}$and $\delta^{18} \mathrm{O}-\mathrm{NO}_{3}^{-}$ values from 6 to $160 \mathrm{~km}$ down-estuary indicates nitrification dominates this portion of the estuary (supported by the nitrate isotope mixing model results) because the process of nitrification, which converts ammonia to nitrate results in lighter nitrate isotopes being generated through fractionation (Kendall et al., 2007; Vavilin, 2014). However, the decline in $\delta^{15} \mathrm{~N}-\mathrm{NO}_{3}^{-}$and $\delta^{18} \mathrm{O}-\mathrm{NO}_{3}^{-}$loads corresponding to the decline in overall $\mathrm{NO}_{3}^{-}$loads down-estuary also suggests that the heavy nitrate isotopes are being removed as well as the light isotopes. The disappearance of $\delta^{15} \mathrm{~N}^{-N^{-}} \mathrm{O}_{3}^{-}$and $\delta^{18} \mathrm{O}$ $\mathrm{NO}_{3}^{-}$down-estuary, where $\mathrm{NO}_{3}^{-}$concentrations are very low $\left(\sim 0.01 \mathrm{mg} \mathrm{L}^{-1}\right)$, may indicate that assimilation or even denitrification is occurring on the remaining heavy $\delta^{15} \mathrm{~N}-\mathrm{NO}_{3}^{-}$ or $\delta^{18} \mathrm{O}-\mathrm{NO}_{3}^{-}$after the lighter $\delta^{14} \mathrm{~N}-\mathrm{NO}_{3}^{-}$or $\delta^{16} \mathrm{O}-\mathrm{NO}_{3}^{-}$is all used up (Fogel and Cifuentes, 1993; Vavilin et al., 2014; Waser et al., 1998a, 1998b).

Seasonal differences in the longitudinal trends for $\delta^{15} \mathrm{~N}$ $\mathrm{NO}_{3}^{-}$and $\delta^{18} \mathrm{O}-\mathrm{NO}_{3}^{-}$suggest differences in biological trans- formations of nitrate due to differences in water temperature, hydrology, and/or $\mathrm{N}$ inputs. The $\delta^{15} \mathrm{~N}^{-\mathrm{NO}_{3}^{-}}$values from effluent inputs were higher in warmer months due likely to higher denitrification rates in the wastewater treatment plant associated with warmer water temperatures (Dawson and Murphy, 1972; Pfenning and McMahon, 1997), resulting in elevated $\delta^{15} \mathrm{~N}-\mathrm{NO}_{3}^{-}$values produced by isotopic fractionation (Kendall et al., 2007; Mariotti et al., 1981). An increase in $\delta^{15} \mathrm{~N}-\mathrm{NO}_{3}^{-}$between 2 and $6 \mathrm{~km}$ down-estuary during summer and fall (Fig. 5b) further shows increased denitrification or biological uptake due to warmer water temperatures and fractionation (Eyre and Ferguson, 2005; Gillooly et al., 2001; Harris and Brush, 2012; Nowicki, 1994). The significant drop in $\delta^{15} \mathrm{~N}-\mathrm{NO}_{3}^{-}$beyond $10 \mathrm{~km}$ down-estuary during summer and fall may have been due to mixing with other $\mathrm{N}$ sources and increased nitrification (Wankel et al., 2006), indicated by the salinity mixing line results. During the spring, there was also a significant decline in $\delta^{15} \mathrm{~N}-\mathrm{NO}_{3}^{-}$between 10 and $160 \mathrm{~km}$ down-estuary, but this was likely attributed to dilution and nitrification, based on the conservative mixing results. The lack of a significant change during the winter, may be due to shorter residence times (Table 2) and cooler temperatures, contributing to lower biological transformation rates. Further down-estuary, near the mouth of the estuary, the increase in $\delta^{18} \mathrm{O}-\mathrm{NO}_{3}^{-}$in winter and spring might indicate denitrification in the estuary but in spring nitrate seems conservative based on the salinity mixing plots. The decline in $\delta^{18} \mathrm{O}-\mathrm{NO}_{3}^{-}$down-estuary in summer and fall suggests that processes other than denitrification in the estuary are controlling the $\delta^{18} \mathrm{O}-\mathrm{NO}_{3}^{-}$, such as nitrification.

\subsection{Isotope and salinity mixing models and influence of temperature and residence time}

Seasonally, the $\sim 2: 1$ relationship between $\delta^{15} \mathrm{~N}-\mathrm{NO}_{3}^{-}$and $\delta^{18} \mathrm{O}-\mathrm{NO}_{3}^{-}$during spring, summer, and fall may indicate denitrification or assimilation, but the salinity mixing plots suggest minimal denitrification in the spring. The fact that the $\delta^{15} \mathrm{~N}: \delta^{18} \mathrm{O}$ ratio is between 1 and 2 for summer and fall may mean assimilation plays a role, which is supported by previous studies that found a $1: 1$ relationship for assimilation in the marine environment (Granger et al., 2004; Karsh et al., $2012,2014)$. However, other previous studies suggest that a $\delta^{15} \mathrm{~N}: \delta^{18} \mathrm{O}$ ratio between 1 and 2 can also be caused by denitrifying bacteria (Granger et al., 2008; Lehmann et al., 2003). The divergence from 2:1 ratio may also be attributed to hotspots of denitrification, such as in hyporheic zones where nitrate is completely consumed by denitrification, resulting in no fractionation (Fogel and Cifuentes, 1993; Vavilin et al., 2014; Waser et al., 1998a, b). Additionally, the divergence from the $2: 1$ ratio in samples further down-estuary may indicate mixing between two or more $\mathrm{NO}_{3}^{-}$sources, such as between atmospheric, marine, or nitrification (Kaushal et al., 2011; Wankel et al., 2006). Due to water column dissolved oxygen levels averaging over $4 \mathrm{mg} \mathrm{L}^{-1}$ (data from Chesa- 
peake Bay Program, not shown), assimilation likely dominates $\mathrm{NO}_{3}^{-}$removal in the water column, while denitrification likely dominates nitrate removal from the sediment, which is supported by previous work (Cornwell et al., 2014; Kemp et al., 1990).

Based on the nitrate isotope mixing model, the longitudinal trends in nitrate sources along the Potomac Estuary correspond to the other results of this study. The decline in wastewater nitrate matched the decline in nitrate concentrations and loads, while the slight increases in nitrification and fertilizer both correspond to a decline in $\mathrm{N}$ and $\mathrm{O}$ isotope values down-estuary and the increase in agricultural land use in the lower Potomac watershed. Future research would benefit from doing the mixing model separately using different endmembers for the different seasons in order to better constrain the differences between seasons. However, due to lack of data on the seasonality of fertilizer and nitrification endmembers, this was not feasible for the scope of this paper. Seasonal endmembers could provide more confidence because we found that seasonality and temperature mattered in the $\mathrm{N}$ sources and loads. Many isotopic studies do not always take this into account and typically just use literature values; our work showed that there are important seasonal variations, and in order to improve the isotope mixing model to capture differences between seasons, the seasonal changes in the endmembers may need to be captured.

Denitrification is likely a sink for $\mathrm{NO}_{3}^{-}$during the summer and fall based on the increases in $\delta^{15} \mathrm{~N}_{-} \mathrm{NO}_{3}^{-}$and $\delta^{18} \mathrm{O}-\mathrm{NO}_{3}^{-}$ within $6 \mathrm{~km}$ down-estuary and due to warmer water temperatures, while there is no evidence for denitrification in the winter due to reduced biological activities typical in cooler winter temperatures (Eyre and Ferguson, 2005; Gillooly et al., 2001; Harris and Brush, 2012; Nowicki, 1994). Nevertheless, nitrate removal was significant in all seasons, including winter, suggesting other mechanisms are important, as indicated by the salinity-based mixing lines.

Plots of salinity vs. $\mathrm{NO}_{3}^{-}, \delta^{15} \mathrm{~N}-\mathrm{NO}_{3}^{-}$, and $\delta^{18} \mathrm{O}-\mathrm{NO}_{3}^{-}$ were used to provide evidence for conservative mixing, uptake, production, or contributions from other $\mathrm{NO}_{3}^{-}$sources. $\mathrm{NO}_{3}^{-}$concentrations fell below the mixing lines during the summer, fall, and winter, suggesting non-conservative mixing behavior due to the presence of a $\mathrm{NO}_{3}^{-}$sink, such as assimilation, denitrification, or burial (Wankel et al., 2006). However, during the spring, $\mathrm{NO}_{3}^{-}$concentrations fell on the mixing line, indicating that there were no important sources or sinks. This may be due to higher flows and shorter residence times in the spring (Table 2), which can result in fewer biological transformations of $\mathrm{NO}_{3}^{-}$. In the salinity vs. $\delta^{15} \mathrm{~N}$ $\mathrm{NO}_{3}^{-}$and $\delta^{18} \mathrm{O}-\mathrm{NO}_{3}^{-}$plots, when the isotope values fell below the mixing lines, this suggested the contribution of $\mathrm{NO}_{3}^{-}$ from sources with lower $\delta^{15} \mathrm{~N}-\mathrm{NO}_{3}^{-}$and $\delta^{18} \mathrm{O}-\mathrm{NO}_{3}^{-}$, such as fertilizer inputs or nitrification, which produces nitrate with lower $\delta^{15} \mathrm{~N}_{-} \mathrm{NO}_{3}^{-}$and $\delta^{18} \mathrm{O}-\mathrm{NO}_{3}^{-}$values through fractionation (Kaushal et al., 2011; Kendall et al., 2007). An increase in nitrification down-estuary is likely attributed to the conversion of remineralized $\mathrm{N}$ to nitrate or from down-estuary inputs of wastewater ammonia that is converted to nitrate (Middelburg and Nieuwenhuize, 2001). During the spring, $\delta^{18} \mathrm{O}_{-\mathrm{NO}_{3}^{-}}$, isotope values again fell mostly on the mixing line, which may indicate the Potomac River estuary is acting more like a transporter instead of a transformer (e.g., Kaushal and Belt, 2012), transporting $\mathrm{NO}_{3}^{-}$without there being any significant sinks of $\mathrm{NO}_{3}^{-}$or mixing with additional sources, likely due to lower residence times (Table 2) in the spring. However, the fact that during the spring the $\delta^{15} \mathrm{~N}_{-} \mathrm{NO}_{3}^{-}$values were slightly below the mixing line indicates that there may have been an increased amount of nitrate inputs from the watershed through runoff carrying nitrate produced by nitrification. During the winter, $\delta^{15} \mathrm{~N}_{-} \mathrm{NO}_{3}^{-}$values also fell above the mixing line for some samples, which suggested the contribution of heavy $\delta^{15} \mathrm{~N}-\mathrm{NO}_{3}^{-}$from an additional downestuary source (potentially from one of the 14 other wastewater treatment plants in the lower Potomac watershed). This was likely not the case during the summer and fall, when other sources and sinks may dominate due to greater biological activities (Eyre and Ferguson, 2005; Gillooly et al., 2001; Harris and Brush, 2012; Nowicki, 1994), or during the spring, when there is more conservative behavior due to higher flows. Even though only surface water salinity, nutrient, and isotope values were used in these mixing line plots, when bottom water nutrient and isotope data were averaged with the surface water values, the mixing lines plots and results did not change (data not shown).

\section{Conclusions}

By coupling isotope tracking techniques and a mass balance over broader spatial and temporal scales, we found that an urban river-estuarine continuum in the Chesapeake Bay, and likely similar estuaries globally can transform anthropogenic inputs of $\mathrm{N}$ over relatively short spatial scales. Only a small fraction of $\mathrm{N}$ inputs from a major wastewater treatment plant were exported out of the estuary. However, processing of $\mathrm{N}$ by estuaries can vary considerably across seasons and hydrologic extremes, with greater exports during periods of higher flows and cooler temperatures, and greater transformations and retention during longer hydrologic residence times and warmer temperatures. In particular, this study supports previous work, showing that non-point sources of $\mathrm{N}$ were more dominant during winter and spring, when runoff from the watershed and estuarine flows were higher, compared to summer and fall, when the point-sources were more dominant, due to lower flows. These differences suggest $\mathrm{N}$ processing in urban rivers and estuaries would differ from those in non-urban estuaries. Also, the potential for long-term and widespread increase in water temperatures as well as frequency and magnitude of droughts and floods through climate change (Kaushal et al., 2010a, b, 2014b) will likely 
influence the sources and transformation of nitrogen to the Chesapeake Bay and estuaries globally. Consequently, future efforts to manage nutrient exports along rivers and estuaries would benefit from a better understanding of the interactive effects of land use and climate variability on the sources, amounts, and transformations of $\mathrm{N}$ exported to coastal waters and targeting critical times for more intensive wastewater treatment.

\section{Data availability}

Data used for the research in this paper are available through 4TU.Centre (2016) at the following DOI: doi:10.4121/uuid:e68c6141-f83e-4375-ac3b-088ddf4eff51.

\section{Information about the Supplement}

The following can be found in the Supplement:

- Additional site information and details on methods

- A table with site coordinates

- A table with the mixing model results

- A table comparing the box model (this study) and Chesapeake Bay Model

- A figure comparing box model results with and without bottom water isotope data

\section{The Supplement related to this article is available online at doi:10.5194/bg-13-6211-2016-supplement.}

Author contributions. This paper is based on work from Michael Pennino's PhD dissertation. Michael Pennino collected water samples, conducted data analysis, and wrote the manuscript. Sujay Kaushal contributed to the study design and provided helpful feedback on data analysis and manuscript writing. Sudhir Murthy contributed to study design, provided data, and contributed to manuscript revisions. Joel Blomquist contributed to study design, sample collection, and manuscript revisions. Jeff Cornwell contributed to manuscript revisions and provided feedback on data analysis. Lora Harris contributed to study design, helped with manuscript writing, and provided significant contributions to data analysis (particularly for the box model mass balance).

Acknowledgements. The historical water quality data used in this study were collected by the Maryland Department of Natural Resources and is available free through the Chesapeake Bay Program's Data Hub website: (www.chesapeakebay.net/data/downloads/cbp_ water_quality_database_1984_present).
This research was supported by the Washington D.C. Water and Sewer Authority. We would like to thank Sally Bowen and Matt Hall from the Maryland Department of Natural Resources (DNR) for their assistance in collecting monthly water samples along the Potomac Estuary and David Brower at the US Geological Survey for help in collecting monthly river input samples for the Potomac River. We acknowledge the input provided by Lewis Linker and Ping Wang of the US EPA Chesapeake Bay Program's Modeling Team for providing simulated output from the CE QUAL ICEM model at three flux boundaries in the Potomac for comparison with our box model output. Gratitude is extended to Jeremy Testa for his suggestions regarding the box model effort. Tom Jordan also provided helpful suggestions.

Edited by: J. Middelburg

Reviewed by: A. E. Giblin and A. F. Bouwman

\section{References}

4TU.Centre: Sources and Transformations of Anthropogenic Nitrogen along an Urban River-Estuarine Continuum, available at: http://doi.org/10.4121/uuid: e68c6141-f83e-4375-ac3b-088ddf4eff51, last access: 08 July 2016.

Aitkenhead-Peterson, J. A., Steele, M. K., Nahar, N., and Santhy, $\mathrm{K}$.: Dissolved organic carbon and nitrogen in urban and rural watersheds of south-central Texas: land use and land management influences, Biogeochemistry, 96, 119-129, 2009.

Betlach, M. R. and Tiedje, J. M.: Kinetic explanation for accumulation of nitrite, nitric-oxide, and nitrous-oxide during bacterial denitrification, Appl. Environ. Microbiol., 42, 1074-1084, 1981.

Billen, G., Somville, M., De Becker, E., and Servais, P.: A nitrogen budget of the Scheldt hydrographical basin, Neth. J. Sea Res., 19, 223-230, 1985.

Boesch, D. F., Brinsfield, R. B., and Magnien, R. E.: Chesapeake Bay eutrophication: Scientific understanding, ecosystem restoration, and challenges for agriculture, J. Environ. Qual., 30, 303320, 2001.

Boynton, W. R., Garber, J. H., Summers, R., and Kemp, W. M.: Inputs, transformations, and transport of nitrogen and phosphorus in Chesapeake Bay and selected tributaries, Estuaries, 18, 285314, 1995.

Boynton, W. R., Hagy, J. D., Cornwell, J. C., Kemp, W. M., Greene, S. M., Owens, M. S., Baker, J. E., and Larsen, R. K.: Nutrient budgets and management actions in the Patuxent River estuary, Maryland, Estuar. Coast., 31, 623-651, 2008.

Buda, A. R. and DeWalle, D. R.: Dynamics of stream nitrate sources and flow pathways during stormflows on urban, forest and agricultural watersheds in central Pennsylvania, USA, Hydrol. Process., 23, 3292-3305, 2009.

Burns, D. A. and Kendall, C.: Analysis of delta(15)N and delta(18)O to differentiate $\mathrm{NO}(3)(-)$ sources in runoff at two watersheds in the Catskill Mountains of New York, Water Resour. Res., 38, 1051, doi:10.1029/2001WR000292, 2002.

Burns, D. A., Boyer, E. W., Elliott, E. M., and Kendall, C.: Sources and Transformations of Nitrate from Streams Draining Varying Land Uses: Evidence from Dual Isotope Analysis, J. Environ. Qual., 38, 1149-1159, 2009. 
Casciotti, K. L., Sigman, D. M., Hastings, M. G., Bohlke, J. K., and Hilkert, A.: Measurement of the oxygen isotopic composition of nitrate in seawater and freshwater using the denitrifier method, Anal. Chem., 74, 4905-4912, 2002.

Cerco, C., Kim, S. C., and Noel, M. R.: The 2010 Chesapeake Bay Eutrophication Model, A Report to the US Environmental Protection Agency and to the US Army Corps of Engineer Baltimore District, US Army Engineer Research and Development Center, Vicksburg, MD, available at: http://www.chesapeakebay.net/ content/publications/cbp_26167.pdf (last access: 7 May 2014), 2010.

Chesapeake Bay Program: CBP Water Quality Database (1984present), http://www.chesapeakebay.net/data/downloads/cbp_ water_quality_database_1984_present, last access: 29 October 2013.

Cornwell, J. C., Glibert, P. M., and Owens, M. S.: Nutrient Fluxes from Sediments in the San Francisco Bay Delta, Estuar. Coast., 37, 1120-1133, 2014.

Cornwell, J. C., Owens, M. S., Boynton, W. R., and Harris, L. A.: Sediment-Water Nitrogen Exchange along the Potomac River Estuarine Salinity Gradient, J. Coast. Res., 32, 776-787, 2016.

Crump, B. C. and Baross, J. A.: Particle-attached bacteria and heterotrophic plankton associated with the Columbia River estuarine turbidity maxima, Mar. Ecol.-Prog. Ser., 138, 265-273, 1996.

Dawson, R. N. and Murphy, K. L.: Temperature dependency of biological denitrification, Water Res., 6, 71-83, 1972.

Divers, M. T., Elliott, E. M., and Bain, D. J.: Quantification of Nitrate Sources to an Urban Stream Using Dual Nitrate Isotopes, Environ. Sci. Technol., 48, 10580-10587, 2014.

Easterling, D. R., Meehl, G. A., Parmesan, C., Changnon, S. A., Karl, T. R., and Mearns, L. O.: Climate extremes: Observations, modeling, and impacts, Science, 289, 2068-2074, 2000.

Elliott, A. J.: The circulation and salinity distribution of the upper Potomac estuary Maryland USA, Chesapeake Science, 17, 141$147,1976$.

Elliott, A. J.: Observations of meteorologically induced circulation in Potomac estuary, Estuar. Coast. Mar. Sci., 6, 285-299, 1978.

Eyre, B. D. and Ferguson, A. J. P.: Benthic metabolism and nitrogen cycling in a subtropical east Australian Estuary (Brunswick): Temporal variability and controlling factors, Limnol. Oceanogr., 50, 81-96, 2005.

Fawcett, S. E., Ward, B. B., Lomas, M. W., and Sigman, D. M.: Vertical decoupling of nitrate assimilation and nitrification in the Sargasso Sea, Deep-Sea Res. Pt. I, 103, 64-72, 2015.

Filoso, S. and Palmer, M. A.: Assessing stream restoration effectiveness at reducing nitrogen export to downstream waters, Ecol. Appl., 21, 1989-2006, 2011.

Fisher, T. R., Gustafson, A. B., Sellner, K., Lacouture, R., Haas, L. W., Wetzel, R. L., Magnien, R., Everitt, D., Michaels, B., and Karrh, R.: Spatial and temporal variation of resource limitation in Chesapeake Bay, Mar. Biol., 133, 763-778, 1999.

Fogel, M. and Cifuentes, L.: Isotope fractionation during primary production, Plenum Press, New York, 1993.

Gillooly, J. F., Brown, J. H., West, G. B., Savage, V. M., and Charnov, E. L.: Effects of size and temperature on metabolic rate, Science, 293, 2248-2251, 2001.

Granger, J., Sigman, D. M., Needoba, J. A., and Harrison, P. J.: Coupled nitrogen and oxygen isotope fractionation of nitrate dur- ing assimilation by cultures of marine phytoplankton, Limnol. Oceanogr., 49, 1763-1773, 2004.

Granger, J., Sigman, D. M., Lehmann, M. F., and Tortell, P. D.: Nitrogen and oxygen isotope fractionation during dissimilatory nitrate reduction by denitrifying bacteria, Limnol. Oceanogr., 53, 2533-2545, 2008.

Hagy, J. D., Sanford, L. P., and Boynton, W. R.: Estimation of net physical transport and hydraulic residence times for a coastal plain estuary using box models, Estuaries, 23, 328-340, 2000.

Hamdan, L. J. and Jonas, R. B.: Seasonal and interannual dynamics of free-living bacterioplankton and microbially labile organic carbon along the salinity gradient of the Potomac River, Estuar. Coast., 29, 40-53, 2006.

Harris, L. A. and Brush, M. J.: Bridging the gap between empirical and mechanistic models of aquatic primary production with the metabolic theory of ecology: An example from estuarine ecosystems, Ecol. Modell., 233, 83-89, 2012.

Hopkinson, C. S. and Vallino, J. J.: The relationships among mans activities in watersheds and estuaries - a model of runoff effects on patterns of estuarine community metabolism, Estuaries, 18, 598-621, 1995.

Horrigan, S. G., Montoya, J. P., Nevins, J. L., and McCarthy, J. $\mathrm{J} .:$ Natural isotopic composition of dissolved inorganic nitrogen in the Chesapeake Bay, Estuar. Coast. Shelf Sci., 30, 393-410, 1990.

IPCC: Climate Change 2007, The Physical Science Basis, Contribution of Working Group I to the Fourth Assessment Report of the Intergovernmental Panel on Climate Change, Cambridge University Press, Cambridge and New York, 2007.

Jaworski, N. A., Groffman, P. M., Keller, A. A., and Prager, J. C.: A watershed nitrogen and phosphorus balance - the upper Potomac River basin, Estuaries, 15, 83-95, 1992.

Jordan, T. E., Weller, D. E., and Correll, D. L.: Sources of nutrient inputs to the Patuxent River estuary, Estuaries, 26, 226-243, 2003.

Jordan, T. E., Cornwell, J. C., Boynton, W. R., and Anderson, J. T.: Changes in phosphorus biogeochemistry along an estuarine salinity gradient: The iron conveyer belt, Limnol. Oceanogr., 53, 172-184, 2008.

Karrh, R., Romano, W., Garrison, S., Michael, B., Hall, M., Coyne, K., Reynolds, D., and Ebersole, B.: Maryland Tributary Strategy Upper Potomac River Basin Summary Report for 1985-2005 Data, Maryland Department of Natural Resources, 2007a.

Karrh, R., Romano, W., Raves-Golden, R., Tango, P., Garrison, S., Michael, B., Baldizar, J., Trumbauer, C., Hall, M., Cole, B., Aadland, C., Trice, M., Coyne, K., Reynolds, D., Ebersole, B., and Karrh, L.: Maryland Tributary Strategy Lower Potomac River Basin Summary Report for 1985-2005 Data, Maryland Department of Natural Resources, 2007b.

Karsh, K. L., Granger, J., Kritee, K., and Sigman, D. M.: Eukaryotic Assimilatory Nitrate Reductase Fractionates $\mathrm{N}$ and $\mathrm{O}$ Isotopes with a Ratio near Unity, Environ. Sci. Technol., 46, 5727-5735, 2012.

Karsh, K. L., Trull, T. W., Sigman, D. M., Thompson, P. A., and Granger, J.: The contributions of nitrate uptake and efflux to isotope fractionation during algal nitrate assimilation, Geochim. Cosmochim. Ac., 132, 391-412, 2014. 
Kaushal, S. S. and Belt, K. T.: The urban watershed continuum: evolving spatial and temporal dimensions, Urban Ecosystems, 15, 409-435, 2012.

Kaushal, S. S., Likens, G. E., Jaworski, N. A., Pace, M. L., Sides, A. M., Seekell, D., Belt, K. T., Secor, D. H., and Wingate, R. L.: Rising stream and river temperatures in the United States, Front. Ecol. Environ., 8, 461-466, 2010a.

Kaushal, S. S., Pace, M. L., Groffman, P. M., Band, L. E., Belt, K. T., Mayer, P. M., and Welty, C.: Land use and climate variability amplify contaminant pulses, EOS, 91, 221-222, 2010 b.

Kaushal, S. S., Groffman, P. M., Band, L. E., Elliott, E. M., Shields, C. A., and Kendall, C.: Tracking Nonpoint Source Nitrogen Pollution in Human-Impacted Watersheds, Environ. Sci. Technol., 45, 8225-8232, 2011.

Kaushal, S. S., Delaney-Newcomb, K., Findlay, S. E. G., Newcomer, T. A., Duan, S., Pennino, M. J., Sivirichi, G. M., SidesRaley, A. M., Walbridge, M. R., and Belt, K. T.: Longitudinal patterns in carbon and nitrogen fluxes and stream metabolism along an urban watershed continuum, Biogeochemistry, 121, 2344, doi:10.1007/s10533-014-9979-9, 2014a.

Kaushal, S. S., Mayer, P. M., Vidon, P. G., Smith, R. M., Pennino, M. J., Duan, S., Newcomer, T. A., Welty, C., and Belt, K. T.: Land use and climate variability amplify carbon, nutrient, and contaminant pulses: a review with management implications, J. Am. Water Resour. Assoc., 50, 585-614, 2014b.

Kaushal, S. S., McDowell, W. H., and Wollheim, W. M.: Tracking evolution of urban biogeochemical cycles: past, present, and future, Biogeochemistry, 121, 1-21, 2014c.

Kemp, W. M., Sampou, P., Caffrey, J., Mayer, M., Henriksen, K., and Boynton, W. R.: Ammonium recycling versus denitrification in Chesapeake Bay sediments, Limnol. Oceanogr., 35, 15451563, 1990.

Kendall, C., Elliott, E. M., and Wankel, S. D.: Tracing anthropogenic inputs of nitrogen to ecosystems, Stable Isotopes in Ecology and Environmental Science, 2nd Edn., doi:10.1002/9780470691854.ch12, 375-449, 2007.

Lehmann, M. F., Reichert, P., Bernasconi, S. M., Barbieri, A., and McKenzie, J. A.: Modelling nitrogen and oxygen isotope fractionation during denitrification in a lacustrine redox-transition zone, Geochim. Cosmochim. Ac., 67, 2529-2542, 2003.

Marconi, D., Weigand, M. A., Rafter, P. A., McIlvin, M. R., Forbes, M., Casciotti, K. L., and Sigman, D. M.: Nitrate isotope distributions on the US GEOTRACES North Atlantic cross-basin section: Signals of polar nitrate sources and low latitude nitrogen cycling, Mar. Chem., 177, 143-156, 2015.

Mariotti, A., Germon, J. C., Hubert, P., Kaiser, P., Letolle, R., Tardieux, A., and Tardieux, P.: Experimental-determination of nitrogen kinetic isotope fractionation - some principles - illustration for the denitrification and nitrification processes, Plant Soil, 62, 413-430, 1981.

Mayer, B., Bollwerk, S. M., Mansfeldt, T., Hutter, B., and Veizer, J.: The oxygen isotope composition of nitrate generated by nitrification in acid forest floors, Geochim. Cosmochim. Ac., 65, 2743-2756, 2001.

Mayer, B., Boyer, E. W., Goodale, C., Jaworski, N. A., Van Breemen, N., Howarth, R. W., Seitzinger, S., Billen, G., Lajtha, L. J., Nosal, M., and Paustian, K.: Sources of nitrate in rivers draining sixteen watersheds in the northeastern US: Isotopic constraints, Biogeochemistry, 57, 171-197, 2002.
Middelburg, J. J. and Nieuwenhuize, J.: Nitrogen isotope tracing of dissolved inorganic nitrogen behaviour in tidal estuaries, Estuar. Coast. Shelf Sci., 53, 385-391, 2001.

Middelburg, J. J. and Nieuwenhuize, J.: Nitrogen uptake by heterotrophic bacteria and phytoplankton in the nitrate-rich Thames estuary, Mar. Ecol.-Prog. Ser., 203, 13-21, 2000.

Milliman, J. D., Shen, H. T., Yang, Z. S., and Meade, R. H.: Transport and deposition of river sediment in the changjiang estuary and adjacent continental-shelf, Cont. Shelf Res., 4, 37-45, 1985.

Nixon, S. W., Ammerman, J. W., Atkinson, L. P., Berounsky, V. M., Billen, G., Boicourt, W. C., Boynton, W. R., Church, T. M., Ditoro, D. M., Elmgren, R., Garber, J. H., Giblin, A. E., Jahnke, R. A., Owens, N. J. P., Pilson, M. E. Q., and Seitzinger, S. P.: The fate of nitrogen and phosphorus at the land sea margin of the North Atlantic Ocean, Biogeochemistry, 35, 141-180, 1996.

Nowicki, B. L.: The effect of temperature, oxygen, salinity, and nutrient enrichment on estuarine denitrification rates measured with a modified nitrogen gas flux technique, Estuar. Coast. Shelf Sci., 38, 137-156, 1994.

Oczkowski, A., Nixon, S., Henry, K., DiMilla, P., Pilson, M., Granger, S., Buckley, B., Thornber, C., McKinney, R., and Chaves, J.: Distribution and trophic importance of anthropogenic nitrogen in Narragansett Bay: An assessment using stable isotopes, Estuar. Coast., 31, 53-69, 2008.

Officer, C. B.: Box models revisited, in: Estuarine and wetland processes, with emphasis on modeling, edited by: Hamilton, P. and Macdonald, K. B., Plenum Press, New York and London, 1980.

Paerl, H. W., Valdes, L. M., Piehler, M. F., and Stow, C. A.: Assessing the effects of nutrient management in an estuary experiencing climatic change: The Neuse River Estuary, North Carolina, Environ. Manage., 37, 422-436, 2006.

Parnell, A. C., Inger, R., Bearhop, S., and Jackson, A. L.: Source Partitioning Using Stable Isotopes: Coping with Too Much Variation, Plos One, 5, 2010.

Parnell, A. C., Phillips, D. L., Bearhop, S., Semmens, B. X., Ward, E. J., Moore, J. W., Jackson, A. L., Grey, J., Kelly, D. J., and Inger, R.: Bayesian stable isotope mixing models, Environmetrics, 24, 387-399, 2013.

Petrone, K. C.: Catchment export of carbon, nitrogen, and phosphorus across an agro-urban land use gradient, Swan-Canning River system, southwestern Australia, J. Geophys. Res.-Biogeo., 115, G01016, doi:10.1029/2009JG001051, 2010.

Pfenning, K. S. and McMahon, P. B.: Effect of nitrate, organic carbon, and temperature on potential denitrification rates in nitraterich riverbed sediments, J. Hydrol., 187, 283-295, 1997.

Pritchard, D. W.: The dynamic structure of a coastal plain estuary, J. Mar. Res., 15, 33-42, 1956.

R Development Core Team: http://www.R-project.org (last access: 15 June 2016), 2013.

Rafter, P. A., DiFiore, P. J., and Sigman, D. M.: Coupled nitrate nitrogen and oxygen isotopes and organic matter remineralization in the Southern and Pacific Oceans, J. Geophys. Res.-Oceans, 118, 4781-4794, 2013.

Sanford, L. P., Suttles, S. E., and Halka, J. P.: Reconsidering the physics of the Chesapeake Bay estuarine turbidity maximum, Estuaries, 24, 655-669, 2001.

Saunders, M. A. and Lea, A. S.: Large contribution of sea surface warming to recent increase in Atlantic hurricane activity, Nature, 451, 557-553, 2008. 
Sigman, D. M., Casciotti, K. L., Andreani, M., Barford, C., Galanter, M., and Bohlke, J. K.: A bacterial method for the nitrogen isotopic analysis of nitrate in seawater and freshwater, Anal. Chem., 73, 4145-4153, 2001.

Smart, S. M., Fawcett, S. E., Thomalla, S. J., Weigand, M. A., Reason, C. J. C., and Sigman, D. M.: Isotopic evidence for nitrification in the Antarctic winter mixed layer, Global Biogeochem. Cy., 29, 427-445, 2015.

Testa, J. M., Kemp, W. M., Boynton, W. R., and Hagy, J. D.: LongTerm Changes in Water Quality and Productivity in the Patuxent River Estuary: 1985 to 2003, Estuar. Coast., 31, 1021-1037, 2008.

US-EPA: Clean Water Act, United States Environmental Protection Agency, http://cfpub.epa.gov/npdes/cwa.cfm (last access: 19 June 2014), 1972.

US-EPA: US Environmental Protection Agency, National Pollutant Discharge Elimination System (NPDES), http://cfpub.epa.gov/ npdes/ (last access: 19 June 2014), 2009.

US-EPA: US Environmental Protection Agency, National Pollutant Discharge Elimination System (NPDES) Stormwater Program, 2011.

US EPA: Concentrated Animal Feeding Operations (CAFOs) per County Downloadable Package, US, 2013, US Environmental Protection Agency, http://catalog.data.gov/dataset/concentratedanimal-feeding, last access: 22 September 2016.

USGS: US Geological Survey Surface Water Data, http://waterdata. usgs.gov/md/nwis/uv?01646500 (last access: 11 June 2014), 2014.

Vavilin, V. A.: Describing a Kinetic Effect of Fractionation of Stable Nitrogen Isotopes in Nitrification Process, Water Resour., 41, 325-329, 2014.

Vavilin, V. A., Rytov, S. V., and Lokshina, L. Y.: Non-linear dynamics of nitrogen isotopic signature based on biological kinetic model of uptake and assimilation of ammonium, nitrate and urea by a marine diatom, Ecol. Modell., 279, 45-53, 2014.
Vitousek, P. M., Aber, J. D., Howarth, R. W., Likens, G. E., Matson, P. A., Schindler, D. W., Schlesinger, W. H., and Tilman, D.: Human alteration of the global nitrogen cycle: Sources and consequences, Ecol. Appl., 7, 737-750, 1997.

Wang, S. Q., Tang, C. Y., Song, X. F., Yuan, R. Q., Wang, Q. X., and Zhang, Y. H.: Using major ions and delta N-15-NO3- to identify nitrate sources and fate in an alluvial aquifer of the Baiyangdian lake watershed, North China Plain, Environmental ScienceProcesses \& Impacts, 15, 1430-1443, 2013.

Wankel, S. D., Kendall, C., Francis, C. A., and Paytan, A.: Nitrogen sources and cycling in the San Francisco Bay Estuary: A nitrate dual isotopic composition approach, Limnol. Oceanogr., 51, 1654-1664, 2006

Waser, N. A., Yin, K. D., Yu, Z. M., Tada, K., Harrison, P. J., Turpin, D. H., and Calvert, S. E.: Nitrogen isotope fractionation during nitrate, ammonium and urea uptake by marine diatoms and coccolithophores under various conditions of $\mathrm{N}$ availability, Mar. Ecol.-Prog. Ser., 169, 29-41, 1998a.

Waser, N. A. D., Harrison, P. J., Nielsen, B., Calvert, S. E., and Turpin, D. H.: Nitrogen isotope fractionation during the uptake and assimilation of nitrate, nitrite, ammonium, and urea by a marine diatom, Limnol. Oceanogr., 43, 215-224, 1998 b.

Wiegert, R. G. and Penaslado, E.: Nitrogen-pulsed systems on the coast of northwest Spain, Estuaries, 18, 622-635, 1995.

Xue, D. M., De Baets, B., Van Cleemput, O., Hennessy, C., Berglund, M., and Boeckx, P.: Use of a Bayesian isotope mixing model to estimate proportional contributions of multiple nitrate sources in surface water, Environ. Pollut., 161, 43-49, 2012.

Yang, Y. Y. and Toor, G. S.: delta N-15 and delta O-18 Reveal the Sources of Nitrate-Nitrogen in Urban Residential Stormwater Runoff, Environ. Sci. Technol., 50, 2881-2889, 2016. 